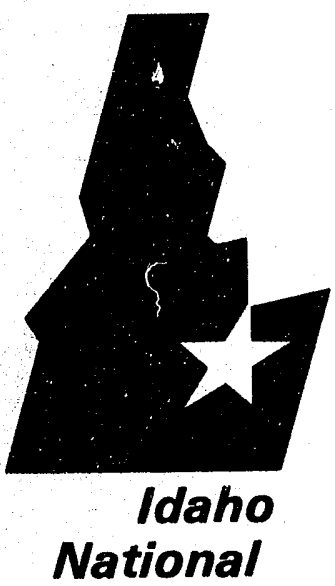

Engineering

Laboratory

Managed

by the U.S.

Department

of Energy
EGG-MS-10613

May 1993
Thermodynamics of Gas-Metal-Slag Equilibria for Applications in In Situ and Ex Situ Vitrification Melts
R. L. Miller

G. A. Reimann

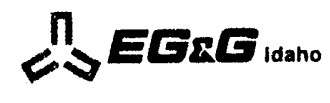

Work performed under DOE Contract No. DE-ACO7-761D01570 
This document contains new concepts or the author(s) interpretation of new calculations and/or measurements; accordingly, EG\&G Idaho, Inc. is iequired by the United States Government to include the following disclaimer:

\section{DISCLAIMER}

This report was prepared as an account of work sponsored by an age ncy of the United States Government. Neither the United States Govemment nor any agency thereof, nor any of their employees, makes any warranty, express or implied, or assumes any legal liability or responsibility for the accuracy, completeness, or usefulness of any information, apparatus, product, or process disclosed, or represents that its use would not infringe privately owned rights. Reference herein to any specific cornmercial product, process, or service by trade name, trademark, manufacturer, or otherwise, does not necessarily constitute or imply its endorsement, recommendation, or favoring by the United States Govemment or any agency thereoi. The views and opinions of authors expressed hurein do not necessarily state or reflect those of the United States Govemment or any agency thereof. 


\title{
Thermodynamics of Gas-Metal-Slag Equilibria for Applications in In Situ and Ex Situ Vitrification Melts
}

\author{
R. L. Miller
}

G. A. Reimann

Published May 1993

\author{
Idaho National Engineering Laboratory \\ EG\&G Idaho, Inc. \\ Idaho Falls, Idaho 83415
}

Prepared for the

U.S. Department of Energy

Office of Environmental Restoration and Waste Management Under DOE Idaho Field Office Contract DE-AC07-76ID01570 


\section{ABSTRACT}

An equilibrium thermodynamic model for melting mixed waste was evaluated using the STEPSOL computer code. STEPSOL uses free energy minimization techniques to predict equilibrium composition from input species and user selected species in the output. The model assumes equilibrium between gas, slag, and metallic phases. Input for the model was developed using compositional data from Pit 9 of the Subsurface Disposal Area at the Idaho National Engineering Laboratory. Thermodynamic data were primarily from compilations published by the U.S. Government. The results of model evaluation indicate that the amount of plutonium chloride or plutonium oxyhydroxide that would be evaporated into the vapor phase would be minor. Relatively more uranium chloride and uranium oxyhydroxide would be vaporized. However, a hazards analysis was not part of the present task. Minor amounts of plutonium and uranium would be reduced to the metallic state, but these amounts should alloy with the iron-chromium-nickel metallic phase. The vast majority of the plutonium and uranium are in the slag phase as oxides. Results of the calculations show that silica and silicates dominate the products and that the system is very reducing. The major gases are carbon monoxide and hydrogen, with lesser amounts of carbon dioxide and water. High vapor pressure metals are considered but were not analyzed using STEPSOL. STEPSOL does not make predictions of distribution of species between phases. 


\section{CONTENTS}

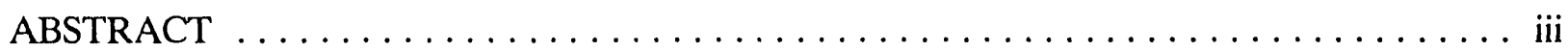

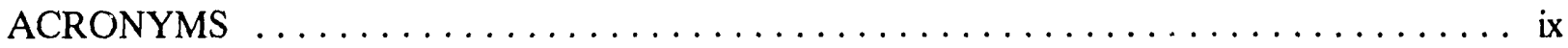

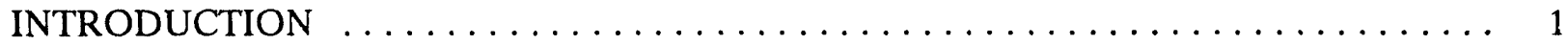

Equilibrium Thermodynamics in Slag-Metal Melts $\ldots \ldots \ldots \ldots \ldots \ldots \ldots \ldots \ldots$

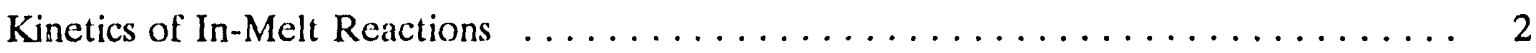

EQUILIBRIUM THERMODYNAMICS $\ldots \ldots \ldots \ldots \ldots \ldots \ldots \ldots \ldots \ldots \ldots$

Ellingham Diagrams $\ldots \ldots \ldots \ldots \ldots \ldots \ldots \ldots \ldots \ldots \ldots \ldots \ldots \ldots \ldots$

Distribution of Uranium and Transuranics $\ldots \ldots \ldots \ldots \ldots \ldots \ldots \ldots \ldots \ldots$

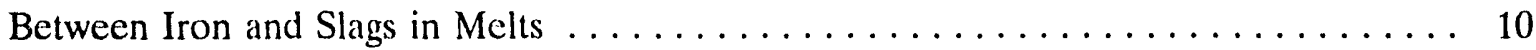

COMPUTER CODES $\ldots \ldots \ldots \ldots \ldots \ldots \ldots \ldots \ldots \ldots \ldots \ldots \ldots \ldots \ldots \ldots$

THERMODYNAMIC DATA BASES $\ldots \ldots \ldots \ldots \ldots \ldots \ldots \ldots \ldots \ldots \ldots \ldots \ldots$

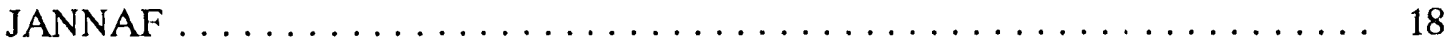

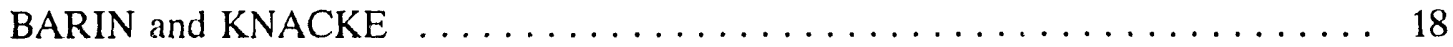

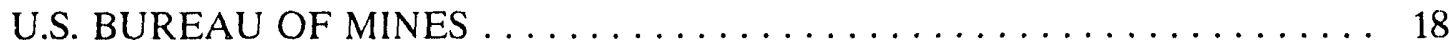

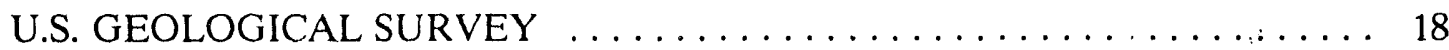

TEXAS A\&M UNIVERSITY $\ldots \ldots \ldots \ldots \ldots \ldots \ldots \ldots \ldots \ldots \ldots \ldots$

BASELINE COMPOSITION $\ldots \ldots \ldots \ldots \ldots \ldots \ldots \ldots \ldots \ldots \ldots \ldots \ldots$

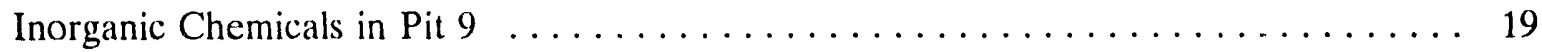

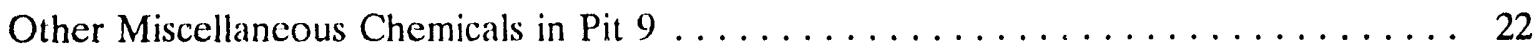

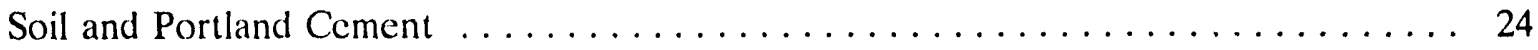

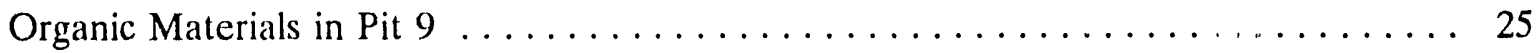

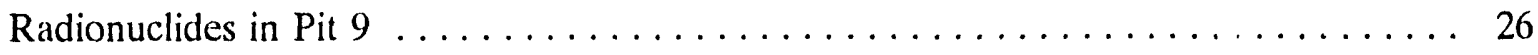

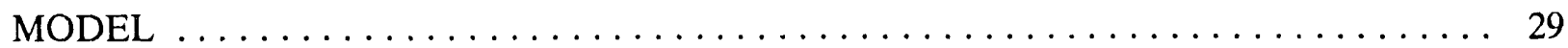

Temperature $\ldots \ldots \ldots \ldots \ldots \ldots \ldots \ldots \ldots \ldots \ldots \ldots \ldots \ldots \ldots \ldots \ldots \ldots \ldots$

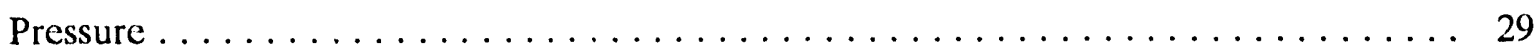




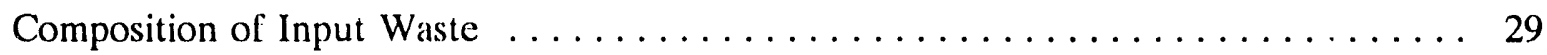

Composition of Output Streams .......................... 29

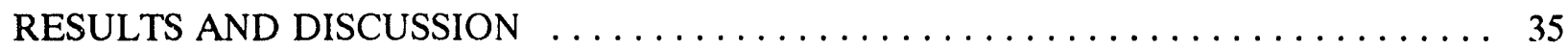

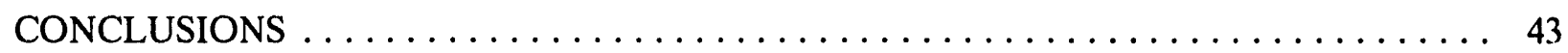

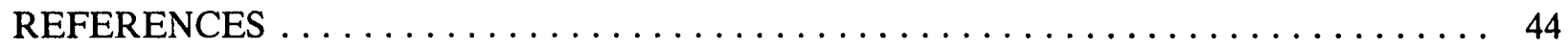

\section{FIGURES}

1. Ellingham diagrams for water, carbon monoxide, and carbon dioxide, methane, hydrogen chloride, and carbon tetrachloride, $\mathrm{kJ} /$ mole of oxygen, $\mathrm{O}_{2}$, chlorine, $\mathrm{Cl}_{2}$, or

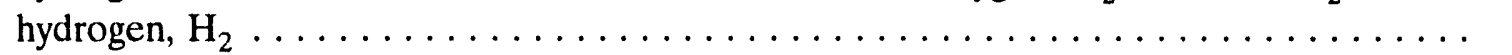

2. Ellingham diagrams for iron oxides, $\mathrm{kJ} /$ mole of oxygen, $\mathrm{O}_{2} \ldots \ldots \ldots \ldots$

3. Temperature-composition diagram for the iron-oxygen system $\ldots \ldots \ldots \ldots$

4. Ellingham diagrams for water, carbon monoxide, carbon dioxide and iron oxides,

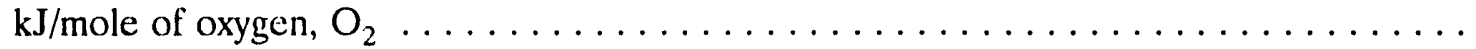

5. Ellingham diagrams for uranium oxides, oxyhydroxide and chlorides, $\mathrm{kJ} / \mathrm{mole}$ of oxygen,

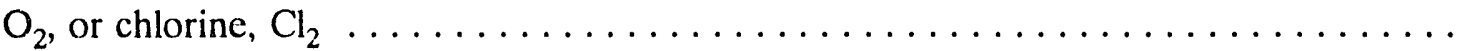

6. Ellingham diagrams for water, carbon monoxide, carbon dioxide, and uranium compounds, $\mathrm{kJ} / \mathrm{mole}$ of oxygen, $\mathrm{O}_{2}$, or chlorine, $\mathrm{Cl}_{2} \ldots \ldots \ldots \ldots \ldots \ldots \ldots$

7. Ellingham diagrams for plutonium oxides, oxyhydroxide and thrichloride, $\mathrm{kJ} / \mathrm{mole}$ of

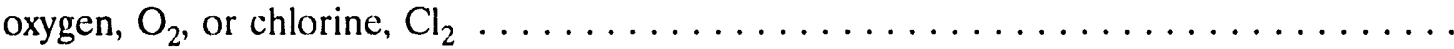

8. Ellingham diagrams for water, carbon monoxide, carbon dioxide, and plutonium compounds, $\mathrm{kJ} / \mathrm{mole}$ of oxygen, $\mathrm{O}_{2}$, or chlorine, $\mathrm{Cl}_{2} \ldots \ldots \ldots \ldots \ldots \ldots$

9. Ellingham diagrams for silicon dioxide, zirconium dioxide, aluminum oxide, and calcium

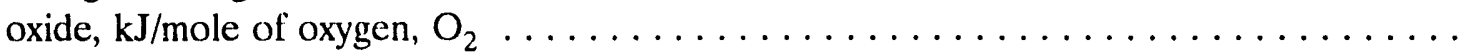

10. Ellingham diagrams for aluminum oxide, zirconium oxide and uranium compounds, $\mathrm{kJ} /$ mole of oxygen, $\mathrm{O}_{2}$, or chlorine, $\mathrm{Cl}_{2}$

11. Ellingham diagrams for aluminum oxide, silicon dioxide, and plutonium compounds, $\mathrm{kJ} /$ mole of oxygen, $\mathrm{O}_{2}$, or chlorine, $\mathrm{Cl}_{2} \ldots \ldots \ldots \ldots \ldots \ldots \ldots \ldots \ldots \ldots \ldots \ldots \ldots \ldots \ldots \ldots \ldots$

12. Temperature-composition diagram for the iron-uranium system $\ldots \ldots \ldots \ldots \ldots$

13. Temperature-composition diagram for the iron-plutonium system 
14. Vapor pressure of zinc and selected higher vapor pressure metals as a function of temperature

15. Vapor pressure of zinc and selected lower vapor pressure metals as a function of temperature

\section{TABLES}

1. Inorganic components of Pit 9 for modeling purposes $\ldots \ldots \ldots \ldots \ldots \ldots$

2. Components equivalent to organic chemicals in Pit 9 for modeling purposes $\ldots \ldots \ldots 25$

3. Radioisotopes in Pit 9 for modeling purposes $\ldots \ldots \ldots \ldots \ldots \ldots \ldots \ldots$

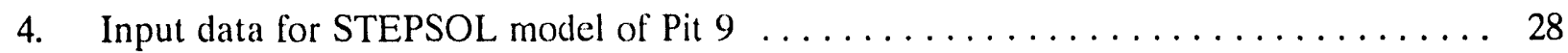

5. Constituents of the output gas phase $\ldots \ldots \ldots \ldots \ldots \ldots \ldots \ldots \ldots \ldots \ldots \ldots \ldots \ldots$

6. Slag phase species that would be generated from the materials in Pit $9 \ldots \ldots \ldots$

7. Uranium and plutonium species that would be generated from the materials in

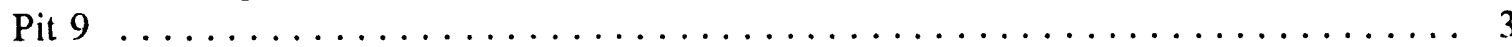

8. Metallic phase species that would be generated from the materials in Pit $9 \ldots \ldots$. $\ldots . .34$

9. Calculated masses of gas, slag, and metal phases that would be generated from

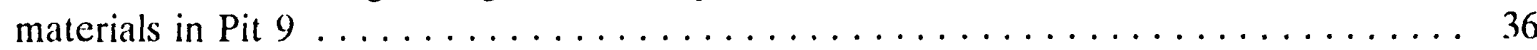

10. Calculated masses of uranium and plutonium species that would be generated from

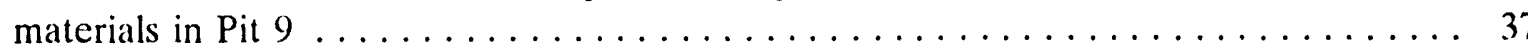

11. Calculated masses of gas phase species that would be generated from materials

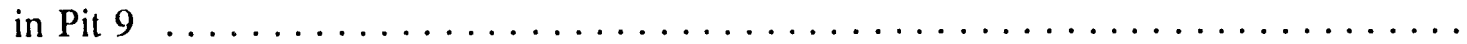

12. Calculated masses of metallic phase species that would be generated from materials in Pit 9

13. Calculated masses of slag phase species that would be generated from materials in Pit 9 


\section{ACRONYMS}

$\begin{array}{ll}\text { ALRC } & \text { Albany (Oregon) Rescarch Center } \\ \text { ANL } & \text { Argonne National Laboratory } \\ \text { CFR } & \text { Code of Federal Regulations } \\ \text { HVPM } & \text { high vapor pressure metal } \\ \text { IBM-PC } & \text { International Business Machines (Corp.) personal computer } \\ \text { INEL } & \text { Idaho National Enginecring Laboratory } \\ \text { ISV } & \text { in situ vitrilication } \\ \text { LLCM } & \text { low-level contaminated metal } \\ \text { ORNL } & \text { Oak Ridge National Laboratory } \\ \text { PC } & \text { personal computer } \\ \text { SDA } & \text { Solids Disposal Area } \\ \text { SI } & \text { Le Systeme International D' Unites (International System of Units) } \\ \text { TRU } & \text { transuranic } \\ \text { USG } & \text { University ol Missouri, Rolla }\end{array}$




\section{Thermodynamics of Gas-Metal-Slag Equilibria for Applications in In Situ and Ex Situ Vitrification Melts}

\section{INTRODUCTION}

Three main considerations are addressed in this report: (1) the disposition of uranium and plutonium in the slag-metal system during vitrification of soils and wastes in Pit 9 of the Idaho National Engineering Laboratory (INEL) Solids Disposal Area (SDA), (2) the disposition of uranium and plutonium in a slag-metal system treating the solid residues from an incinerator in a melter to reduce their volume, and (3) the production of plutonium and uranium oxyhydroxides and chlorides that might volatilize and become part of the gaseous emissions from a mixed-waste treatment system. The concepts discussed here are applicable to in situ vitrification (ISV) and to ex situ vitrification, e.g., the slags from an are melter.

One school of thought is that the uranium and plutonium oxides in the wastes might be reduced by carbon or carbon compounds in the soil or in the waste to form uranium or plutonium metal. The problem is the high density of the metals compared to the melt (specific gravity of the metal referenced to the melt) and other materials that would form during waste melting. The high specific gravity of the metals is postulated to result in settling of the metallic particles, resulting in their accumulation in the lower regions of the melt. Too large of a localized mass of plutonium or enriched uranium is postulated to result in a critical mass, in the nuclear sense.

\section{Equilibrium Thermodynamics in Slag-Metal Melts}

In this report, the equilibrium thermodynamics of reactions between carbon and carbon monoxide, or other reducing agents, and the oxides of uranium and plutonium as oxidizing agents are estimated from available data. Other metal and metal oxide systems are also considered, since they are present in the soil and in the waste materials. In particular, zirconium, aluminum, iron, and their oxides are considered because of their presence in the waste materials. These metals and their oxides form a very effective reduction-oxidation "buffer" system in that the iron is reduced relatively casily by carbon, carbon monoxide, aluminum, and zirconium. Ellingham diagrams, described below, are used to identify the products that should be present. The method of making these equilibrium thermodynamic calculations is by using a computer program designed to estimate the Gibbs energy of formation of the various components and to estimate the relative amounts of each product in each phase, using a Gibbs energy minimization algorithm. This computer program is described below.

Uranium and plutonium oxyhydroxides and chlorides are given special consideration because of their high vapor pressures. High vapor pressure metals on the Environmental Protection Agency toxicity list (40 CFR 261.24), viz., arsenic, barium, cadmium, chromium, lead, mercury, selenium, and silver, are analyzed because of their toxicity. Zinc is another high vapor pressure metal included in the evaluation. 
The equilibrium thermodynamies calculations considered here are not dynamic, i.e., they do not consider an advancing front of molten metal/slag/gas. The dynamic problem is somewhat more involved than could be considered in the present task. The dynamic problem would have to consider varying temperatures and the reaction of different materials as the hot zone approached. Further, the temperature of the melt would not be uniform due to heat losses through boundaries of the melt. The cooling portions of the melt would generate a suite of minerals in a glassy matrix. In mineralogical terms, this would be termed facies. The suite of mincrals would change with temperature, reflecting the relative stabilities of the melt composition. Equilibrium thermodynamics could calculate these compositions, but they might not be seen due to slow diffusion in the solick.

\section{Kinetics of In-Melt Reactions}

One aspect of the kinetics problem must not go unstated: equilibrium thermodynamies do not predict kinetics. In the temperature range of interest in slag-metal interactions, a lirst approximation to the kinetics question can be made, viz., the reactions will be mass-transfer controlled. An ISV site resembles a single, very large batch reactor with large thermal and chemical gradients throughout the volume of the reactor. Because of these gradients and of low rates of diffusion of reactants and products, equilibrium will not be achieved. However, this does not restrain us from making calculations that would indicate the probable composition to occur if all materials in the melt were allowed to reach thermodynamic equilibrium. In addition, these calculations could be used to predict behavior in ex situ melters. A second aspect of the thermodynamics/kinetics problem is that, in general, the further removed from equilibrium the faster the rate of reaction.

Benchscale experiments at the INEL have shown that point-source contaminants are redistributed more-or-less uniformly in the melt, except for a thin shell of material adjacent to the outer surface of the crucible. These results suggest that at high temperatures the rates of reaction may not be controlled by dillusion processes. At low temperatures, where the viscosity of the glass is very high, the rates of reaction will likely be diffusion controlled. The cooled mass of the ISV materials resemble a glass, and glasses are actually very viscous liquids. Dilfusion is slow and almost ceases at temperatures less than the glass transition temperature, ${ }^{1}$ becoming similar to the rates of diflusion in metals and ceramics.

Gibbs energy minimization calculations show that the amount of elemental uranium or plutonium present in the alloy phase will be very small, i.e., these elements will be in the slag phase as oxides or chlorides. 


\section{EQUILIBRIUM THERMODYNAMICS}

\section{Ellingham Diagrams}

Scoping calculations were made to estimate the probability of reduction of uranium and plutonium oxides by carbon monoxide and carbon or other reducing agents. These calculations are in the form of Ellingham diagrams, which are graphs of Gibbs energy of formation as a function of absolute temperature. ${ }^{2}$ Compound stability increases (resists reaction) the more negative the Gibbs energy of formation. Figure 1 shows the Ellingham diagrams for carbon dioxide, carbon monoxide, methane, and water. This figures shows that water is the most stable of the compounds and that methane is the least stable at low temperatures. Above approximately $900 \mathrm{~K}$, carbon monoxide becomes the most stable and methane or water the least stable; carbon dioxide has a nearly constant Gibbs energy of formation over the temperature range of interest. Carbon monoxide is more stable than carbon dioxide above approximately $900 \mathrm{~K}$; thus, carbon will react with carbon dioxide to form carbon monoxide. ${ }^{3}$ Methane is of lesser importance at high temperatures.

Ellingham diagrams provide a qualitative indication of the relative stabilities of the compounds being considered. These diagrams do not provide an indication of the relative abundance of the compounds being considered. The amount of the various constituents present, at equilibrium, is provided by Gibbs energy minimization calculations. However, none of these techniques identify the compounds that need to be considered. The program user has to make the proper judgment on this point. For example, in the reactions between carbon, hydrogen, and oxygen, the formation of methane is not evident but needs to be considered. Methane is just the simplest of the hydrocarbon compounds; and the production of other, more complex hydrocarbons such as ethane, ethylene, acetylene, and benzene, may need to be considered in a detailed calculation.

Figure 2 shows the Ellingham diagrams for wuestite, $\mathrm{FeO}$, magnetite, $\mathrm{Fe}_{3} \mathrm{O}_{4}$, and hematite, $\mathrm{Fe}_{2} \mathrm{O}_{3}$. This figure shows that hematite is the least stable of the compounds, except below approximately $400 \mathrm{~K}$. Above approximately $900 \mathrm{~K}$, wuestite is the most stable; below this temperature, magnetite is the most stable. This may be compared with the phase diagram for the iron-oxygen system, shown in Figure $3 .^{2}$ This phase diagram shows that there are regions of stability for all of the oxides, depending on temperature and oxygen content. Figure 3 shows that the iron-oxygen system is complex with respect to stable species; and above approximately 1,900 $\mathrm{K}$, only liquids are present. These liquids are solutions of iron and/or iron oxides. In some cases, the liquids are not miscible, and more than one liquid phase may be present. The impact of this on the slags is that there may be a partitioning of nonferrous species between the separate liquid phases. There are lew data available on the thermodynamic solution activities of species in the liquid phases. However, at equilibrium, the activities of any species are the same in two or more phases in contact.

Figure 4 is an overlay of Figure 1 onto Figure 2 and shows the relative stability of carbon monoxide, carbon dioxide, water, wuestite, magnetite, and hematite. Figure 4 shows that both 


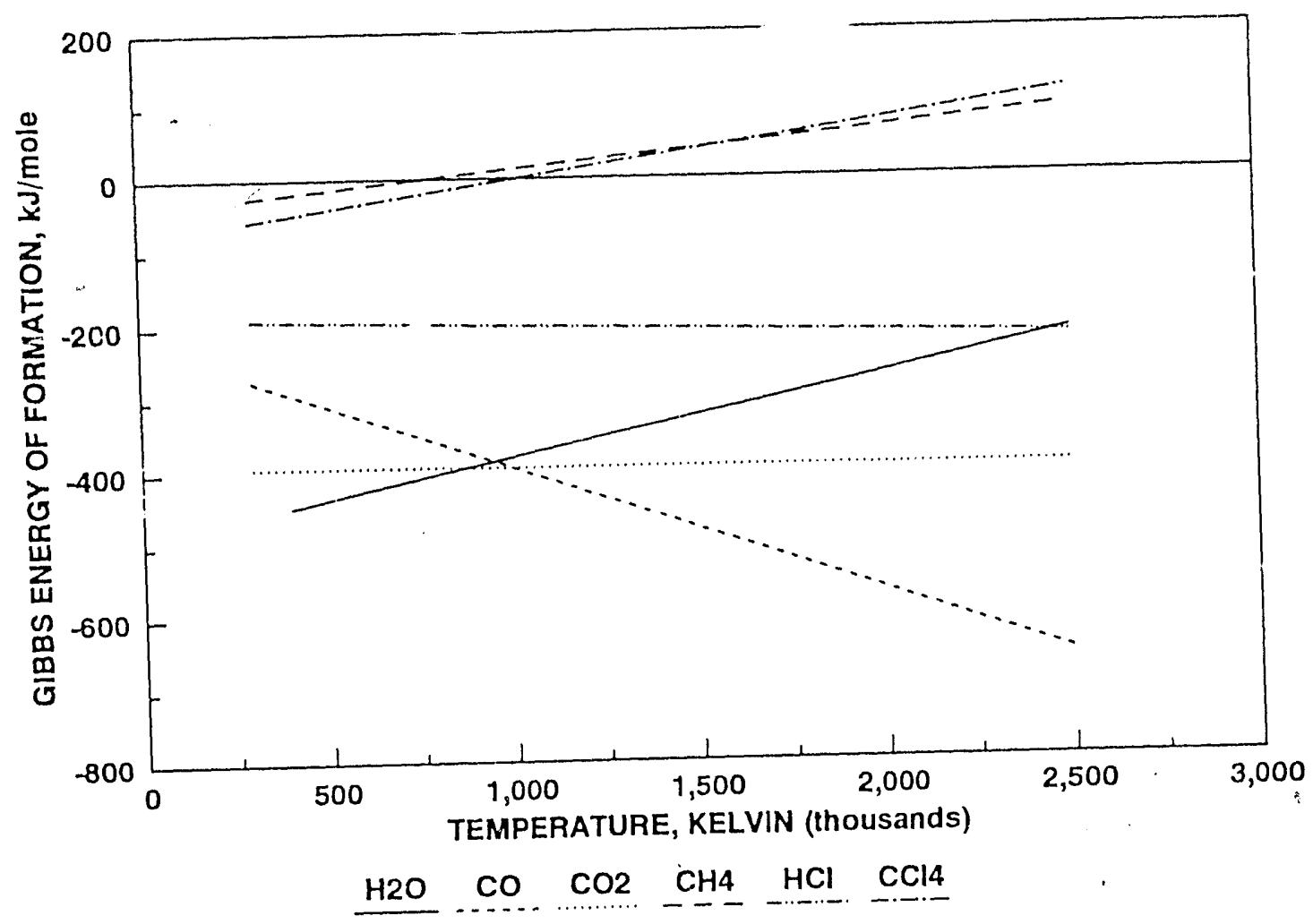

Figure 1. Ellingham diagrams for water, carbon monoxide, and carbon dioxide, methane, hydrogen chloride, and carbon tetrachloride, $\mathrm{kJ} /$ mole of oxygen, $\mathrm{O}_{2}$, chlorine, $\mathrm{Cl}_{2}$, or hydrogen, $\mathrm{H}_{2}$.

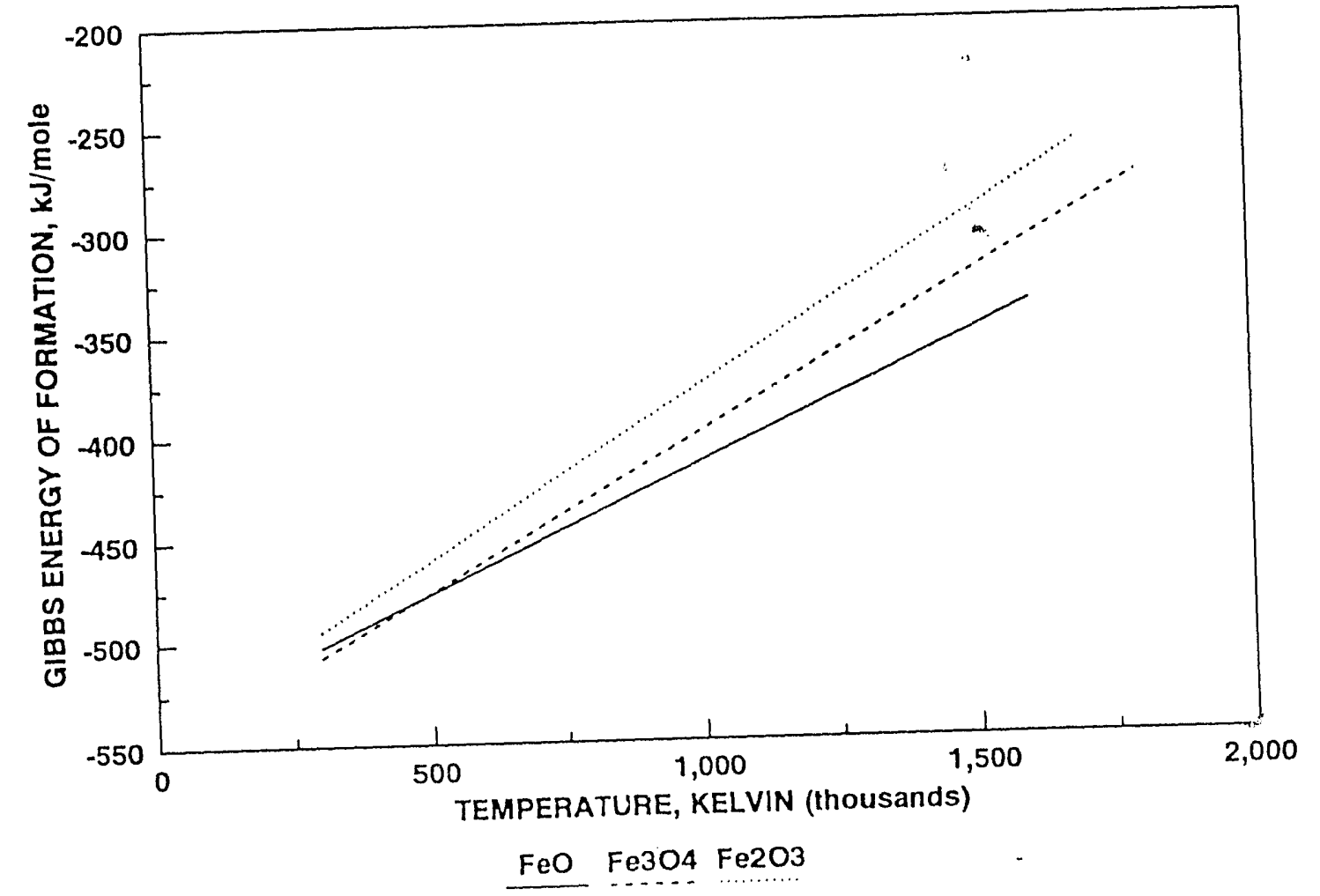

Figure 2. Ellingham diagrams for iron oxides, $\mathrm{kJ} / \mathrm{mole}$ of oxygen, $\mathrm{O}_{2}$. 


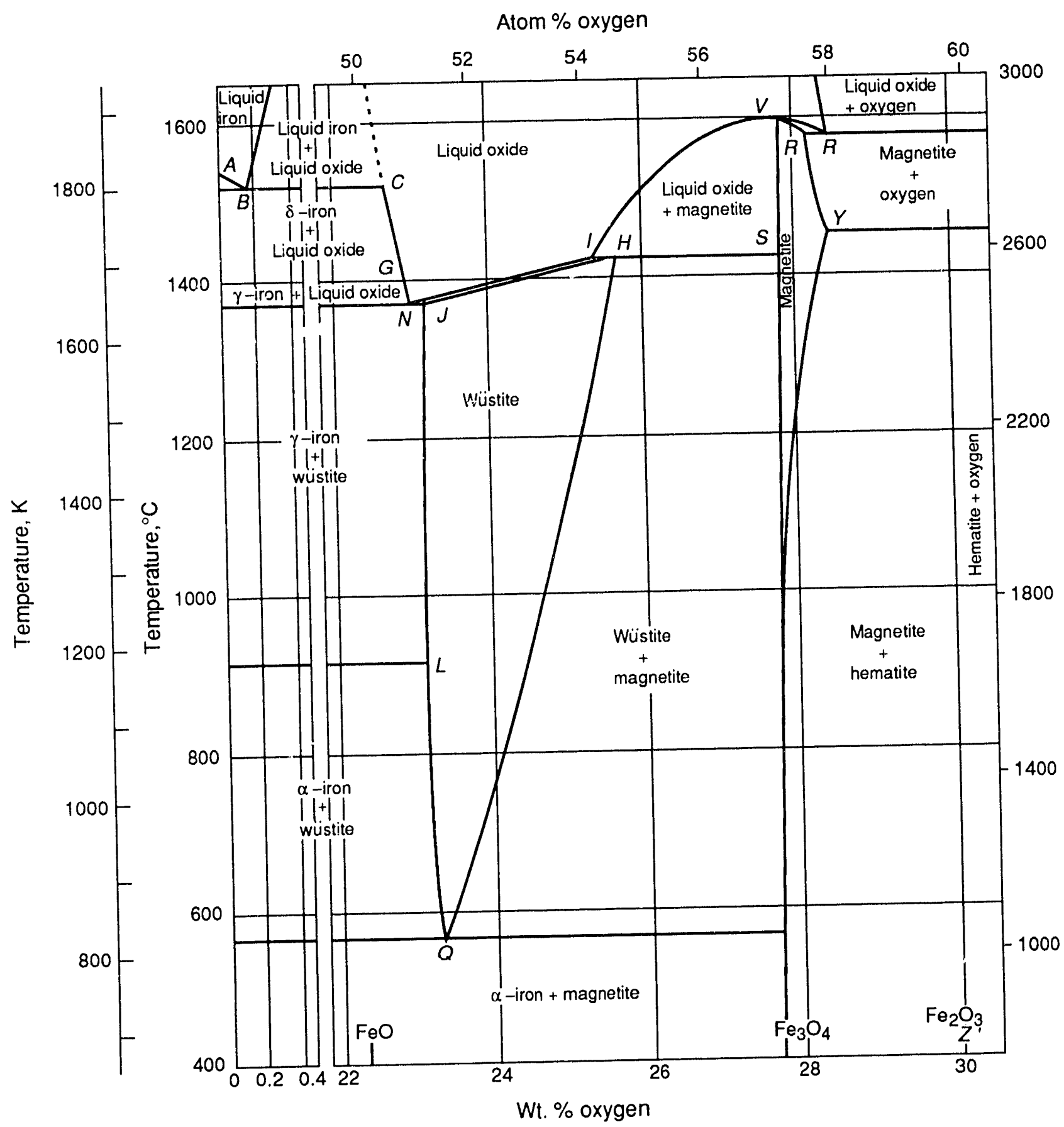

Figure 3. Temperature-composition diagram for the iron-oxygen system. 


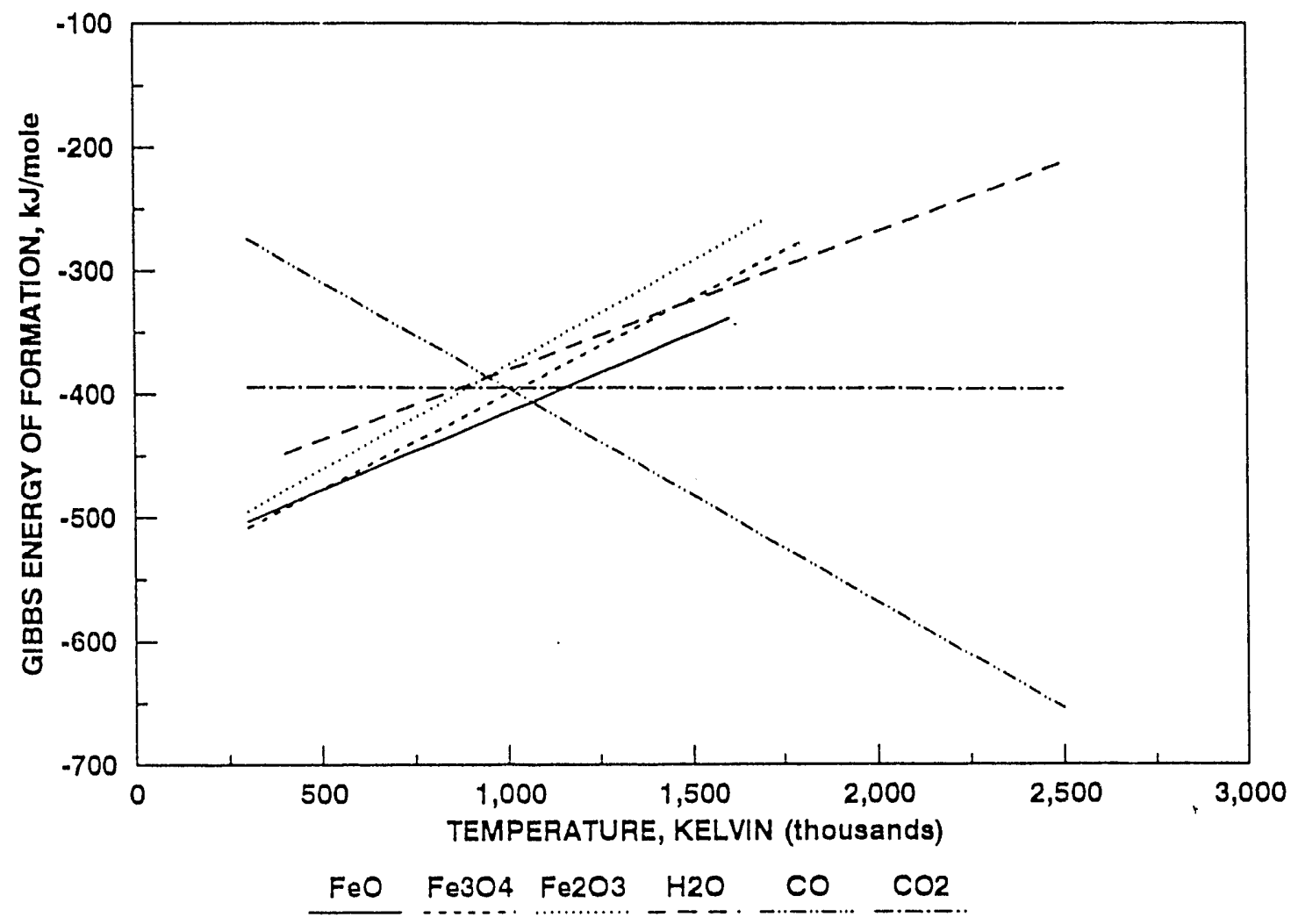

Figure 4. Ellingham diagrams for water, carbon monoxide, carbon dioxide and iron oxides, $\mathrm{kJ} /$ mole of oxygen, $\mathrm{O}_{2}$.

carbon dioxide and carbon monoxide are more stable than any of the iron oxides above approximately $1,000 \mathrm{~K}$ and that the oxides of iron will be redueed by carbon and carbon monoxide to elemental iron and carbon dioxide and carbon monoxide. This figure shows that reduction of iron oxides to elemental iron should be expected during ISV of soils and waste materials. As a first approximation, the iron oxides should be reduced early in the process and consume much of the reducing capacity of the ISV melt. The carbon necessary for the process would be found in the humus of the soils and in plastics, cellulose (in the form of paper, rags, and wood), and other organic materials in the wastes. As a further consideration, these easily reduced oxides form a buffering system in the melt, making it possible to consume the more easily oxidized constituents, such as metallic aluminum and zirconium in the reduction-oxidation process rather than the oxides of uranium and plutonium, discussed below.

Ellingham diagrams for uranium oxides are shown in Figure 5. Data for the Gibbs energy of formation for $\mathrm{UO}_{3}$ are limited to approximately $2,000 \mathrm{~K}$ and for $\mathrm{U}_{4} \mathrm{O}_{9}$ to approximately $900 \mathrm{~K}$. $\mathrm{UO}_{2}$ is the most stable of the uranium oxides, and its data base extends to approximately $2,600 \mathrm{~K}$. The uranium oxides are seen to have very negative Gibbs energies of formation, implying that they will be very dillicult to reduce to the metallic state. Figure 6 is an overlay of Figure 1 onto Figure 5 and shows that $\mathrm{UO}_{2}$, the most stable of the uranium oxides, is not reduced by carbon below approximately $2,500 \mathrm{~K}$. Further evaluation of this system using free energy minimization techniques is required to get a better estimate of the stability of $\mathrm{UO}_{2}$ in this temperature regime. These cvaluations are described in the results section.

Ellingham dia: rams for the plutonium oxides are shown in Figure 7. The data base for these oxides is limited to :,173 $\mathrm{K}$ for $\mathrm{PuO}$, to 2,500 $\mathrm{K}$ for $\mathrm{PuO}_{2}$, and to 2,000 K for $\mathrm{Pu}_{2} \mathrm{O}_{3}$. These 


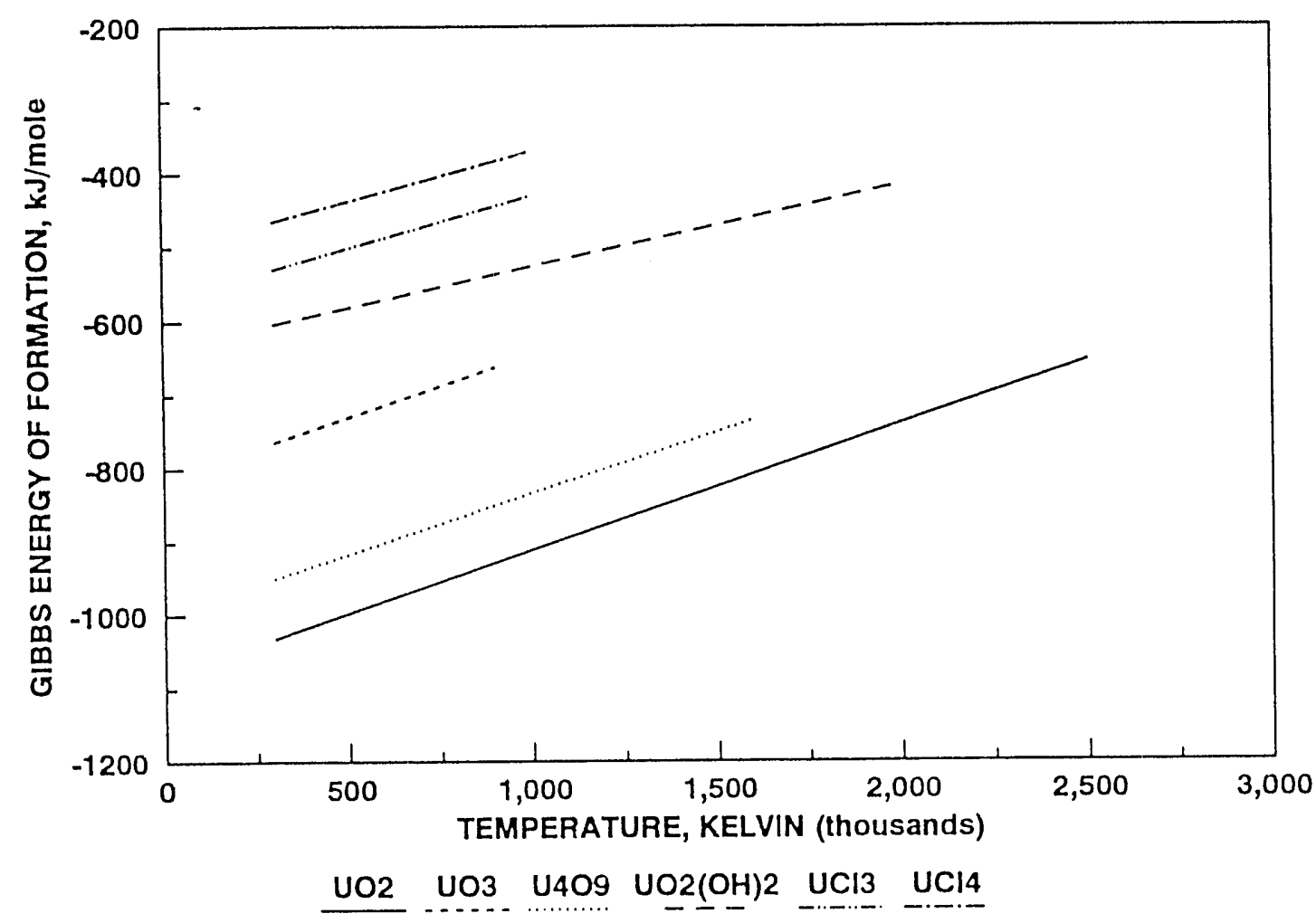

Figure 5. Ellingham diagrams for uranium oxides, oxyhydroxide and chlorides, $\mathrm{kJ} / \mathrm{mole}$ of oxygen, $\mathrm{O}_{2}$, or chlorine, $\mathrm{Cl}_{2}$.

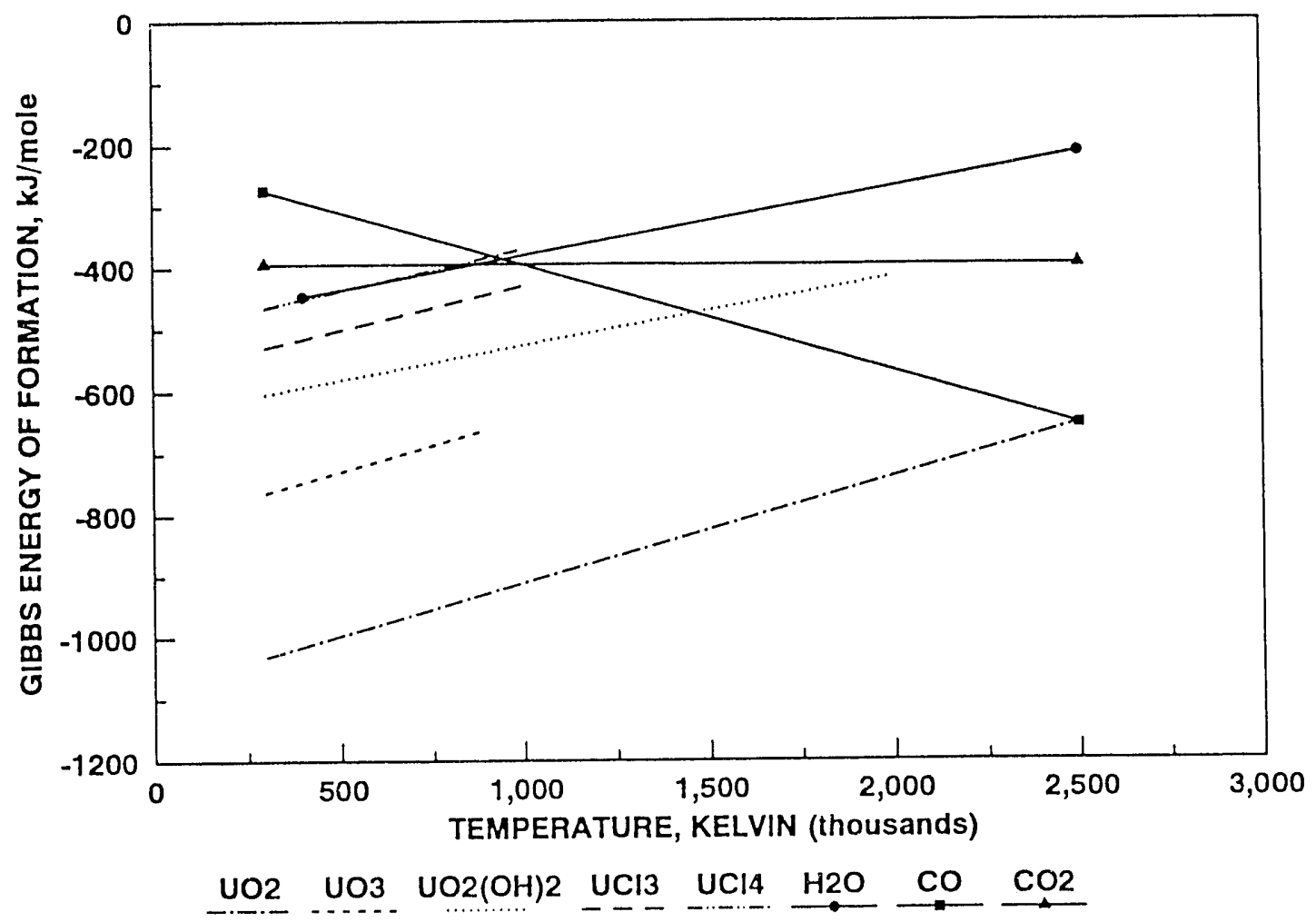

Figure 6. Ellingham diagrams for water, carbon monoxide, carbon dioxide, and uranium compounds, $\mathrm{kJ} / \mathrm{mole}$ of oxygen, $\mathrm{O}_{2}$, or chlorine, $\mathrm{Cl}_{2}$. 


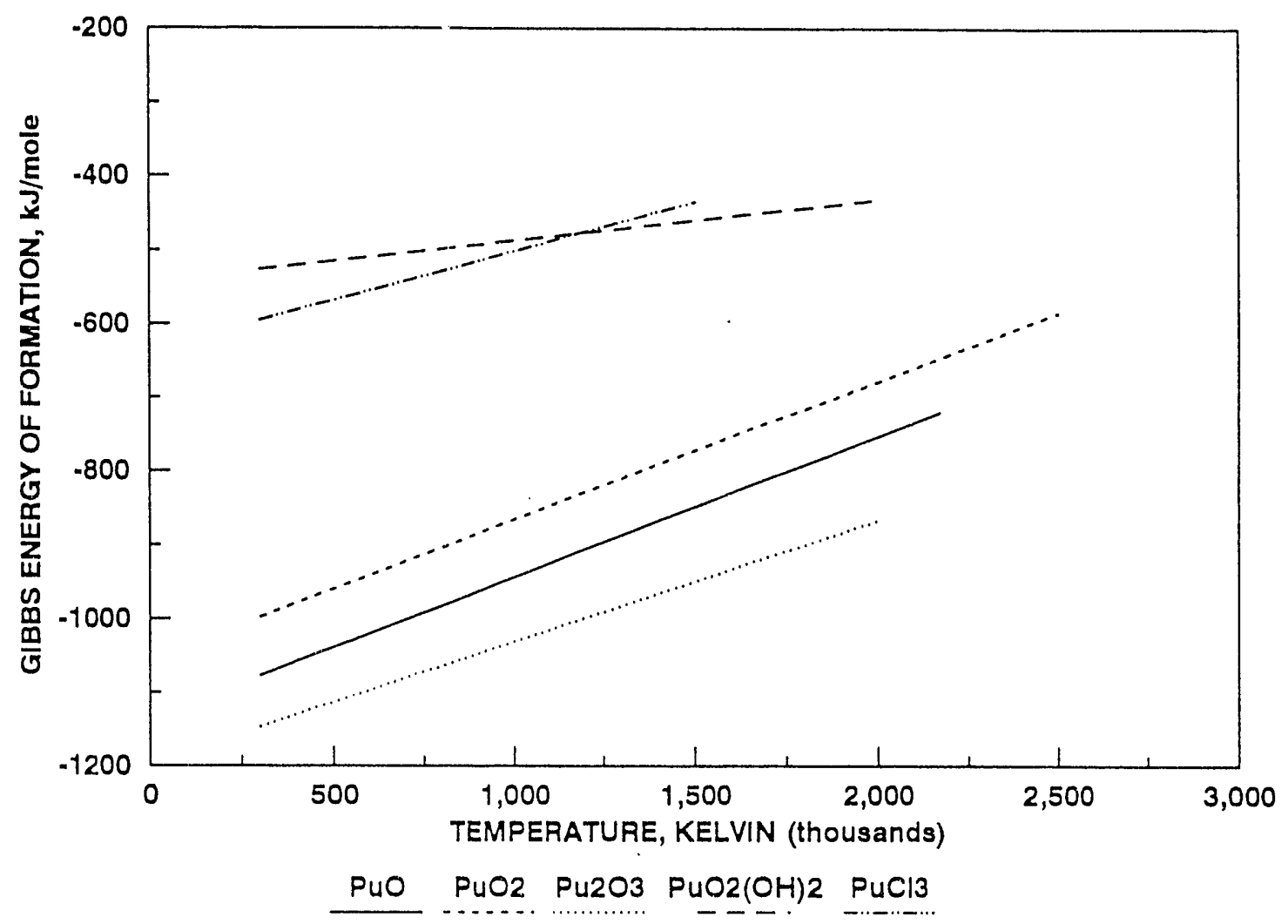

Figure 7. Ellingham diagrams for plutonium oxides, oxyhydroxide and thrichloride, $\mathrm{kJ} / \mathrm{mole}$ of oxygen, $\mathrm{O}_{2}$, or chlorine, $\mathrm{Cl}_{2}$.

oxides are seen to have very negative Gibbs energies of formation; PuO is the least stable of these oxides. Figure 8 is an overlay of Figure 1 onto Figure 7 . The curve for $\mathrm{CO}$ is seen to cross that of $\mathrm{PuO}$ at approximately $2,100 \mathrm{~K}$, indicating that carbon could reduce $\mathrm{PuO}$ above this temperature. Further evaluation of this system using Gibbs energy minimization techniques is required to get a better indication of the stability of $\mathrm{PuO}$ in this temperature regime. These evaluations are described in the results section.

Data for the Ellingham diagrams for plutonium trichloride, $\mathrm{PuCl}_{3}$, were from U.S. Bureau of Mines Bulletin $674 .^{4}$ This compound melts at 1,033 K; and beyond this temperature, we would be dealing with a liquid and probably a solution of various chlorides. These data were limited to $1,500 \mathrm{~K}$ and were extrapolated to $3,000 \mathrm{~K}$. Data published by Rand ${ }^{5}$ for plutonium trichloride compare very favorably with those given in Bulletin 674. Figure 7 compares the data for the plutonium oxides and chlorides. Uranium trichloride, $\mathrm{UCl}_{3}$, melts at $1,115 \mathrm{~K}$ while the tetrachloride, $\mathrm{UCl}_{4}$, melts at $86.3 \mathrm{~K}$. As with plutonium trichloride, or other chlorides, these would probably be present as solutions. The thermodynamic activities of these chlorides in the melt are unknown and assumed to be equal to their stoichiometric concentrations.

Ellingham diagrams for silicon dioxide, $\mathrm{SiO}_{2}$, zirconium dioxide, $\mathrm{ZrO}_{2}$, aluminum oxide, and calcium oxide are shown in Figure 9. Sourees for these oxides are present in Pit 9 in the form of aluminum alloys, zircaloy, soil, sand, and concrete." This ligure does not exhaust the number of important materials in the pit but represents significant constituents. Curves for aluminum and zirconium oxides are seen to cross at approximately $1,000 \mathrm{~K}$, indicating that above this temperature aluminum oxide would be expected to react with zirconium, in zircaloy, for example, to form metallic aluminum and zirconium oxide. (Such a reaction is thought to have occurred in 


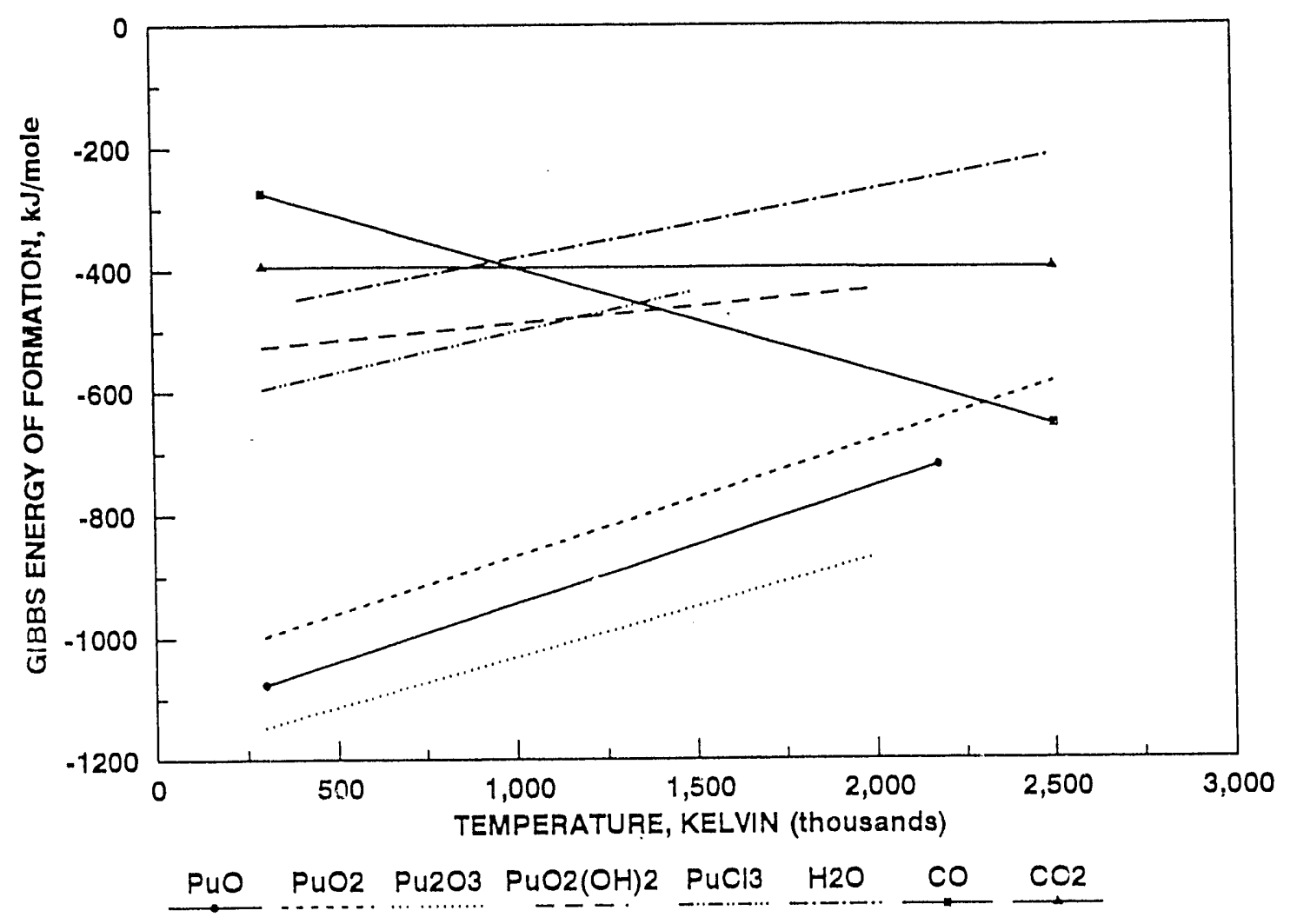

Figure 8. Ellingham diagrams for water, carbon monoxide, carbon dioxide, and plutonium compounds, $\mathrm{kJ} /$ mole of oxygen, $\mathrm{O}_{2}$, or chlorine, $\mathrm{Cl}_{2}$.

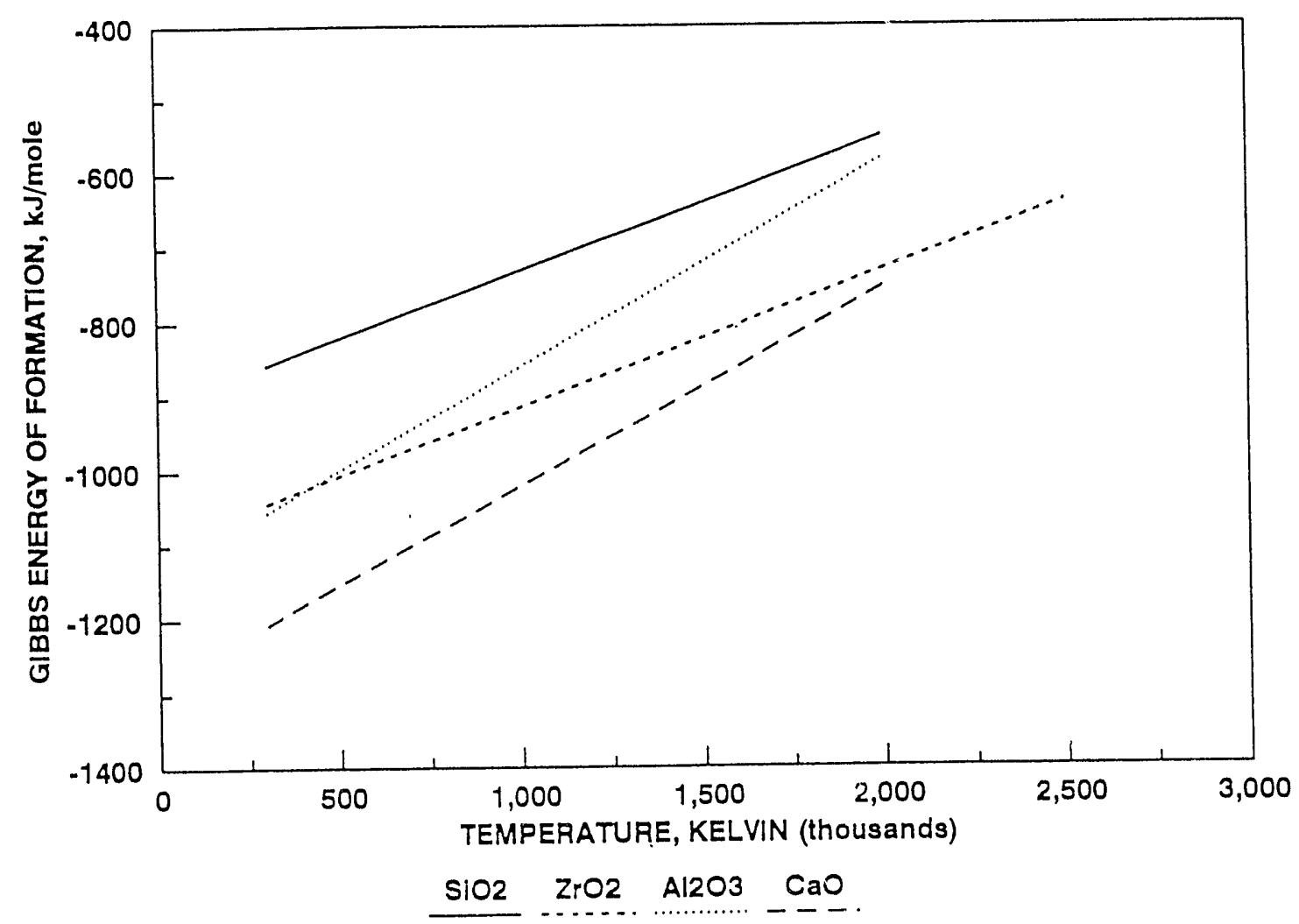

Figure 9. Ellingham diagrams for silicon dioxide, zirconiunı dioxide, aluminum oxide, and calcium oxide, $\mathrm{kJ} / \mathrm{mole}$ of oxygen, $\mathrm{O}_{2}$. 
electrically heated zircaloy-4 clad pins, with alumina insulation, simulating fucl rods in thermal-hydraulic flow tests; the result was loss of the pins and their simulated fuel bundles. ${ }^{7} \mathrm{~A}$ simple thermodynamic analysis of the potential reaction ${ }^{8}$ followed by laboratory evaluation of the materials at the operating temperature showed that the zirconium-aluminum oxide reaction was the probable cause of the heater rod failure. ${ }^{9}$ ) Because of the stability of the oxide films on aluminum and zirconium in air, it is highly probable that these metals are present in Pit 9 in their metallic forms; and the possibility of reaction between these metals and other oxides in the pit should be considered.

\section{Distribution of Uranium and Transuranics Between Iron and Slags in Melts}

Figure 10 is an overlay of the Ellingham diagrams for the uranium oxides from Figure 6 onto the Ellingham diagrams for aluminum and zirconium oxides from Figure 9. Figure 10 shows that aluminum and zirconium oxides are more stable than $\mathrm{UO}_{3}$ or $\mathrm{U}_{4} \mathrm{O}_{9}$, indicating that if these oxides occur in the presence of metallic aluminum or zirconium they could be reduced to their metallic state. However, the amount of silica in Pit 9 is so large that any metallic aluminum or zirconium will most likely reduce the silica to silicon with concurrent formation of aluminum and zirconium oxides, i.e., the silica in Pit 9 will act as a powerful buffer for oxidation-reduction reactions in melts, and elemental silicon should be formed in preference to reduction of uranium oxides to metallic uranium. Figure 9 also shows that $\mathrm{UO}_{2}$ is more stable than either of the oxides of aluminum or zirconium above approximately $1,000 \mathrm{~K}$. However, below approximately $1,000 \mathrm{~K}$, the oxides of aluminum and zirconium are more stable than any of the uranium oxides. This indicates that $\mathrm{UO}_{2}$ could be reduced to metallic uranium by reaction with aluminum or zirconium above $1,000 \mathrm{~K}$. However, this is near the glass transition temperature for the vitrified mass; and under these conditions, the rate of mass transfer is known to be very small. A more detailed analysis is required using Gibbs energy minimization techniques to estimate the relative amounts of the metals that could be formed in the proposed reactions.

Figure 11 is an overlay of the Ellingham diagrams for the plutonium oxides from Figure 7 onto the Ellingham diagrams for aluminum and zirconium oxides from Figure 9. Figure 11 shows that $\mathrm{PuO}$ amd $\mathrm{Pu}_{2} \mathrm{O}_{3}$ are more stable than the oxides of aluminum or zirconium over the temperature range of the data. This indicates that these oxides would not be reduced by metallic aluminum or zirconium to form metallic plutonium and the oxides of aluminum or zirconium.

Figure 11 shows that the oxides of aluminum and zirconium are more stable than PuO, indicating that metallic aluminum or zirconium could reduce this oxide to metallic plutonium. However, it is more probable that the $\mathrm{PuO}_{2}$ would be reduced to $\mathrm{PuO}$ and $\mathrm{Pu}_{2} \mathrm{O}_{3}$, which are more stable than zirconium or aluminum oxides. A lurther consideration is that zirconium and aluminum might be consumed by reducing other oxides such as iron oxides. This buffering action by the more easily reduced oxides is important in the overall analysis of the ISV system. Analysis of this system, with regard to uranium and plutonium, using Gibbs energy minimization techniques is the subject of the present study.

If metallic iron were formed (by carbon reduction, for example) during ISV, it could act as a solvent for trace levels of plutonium and uranium. The iron-uranium and iron-plutonium phase diagrams are shown in Figure 12 and Figure 13, respectively. ${ }^{10}$ These phase diagrams show that 


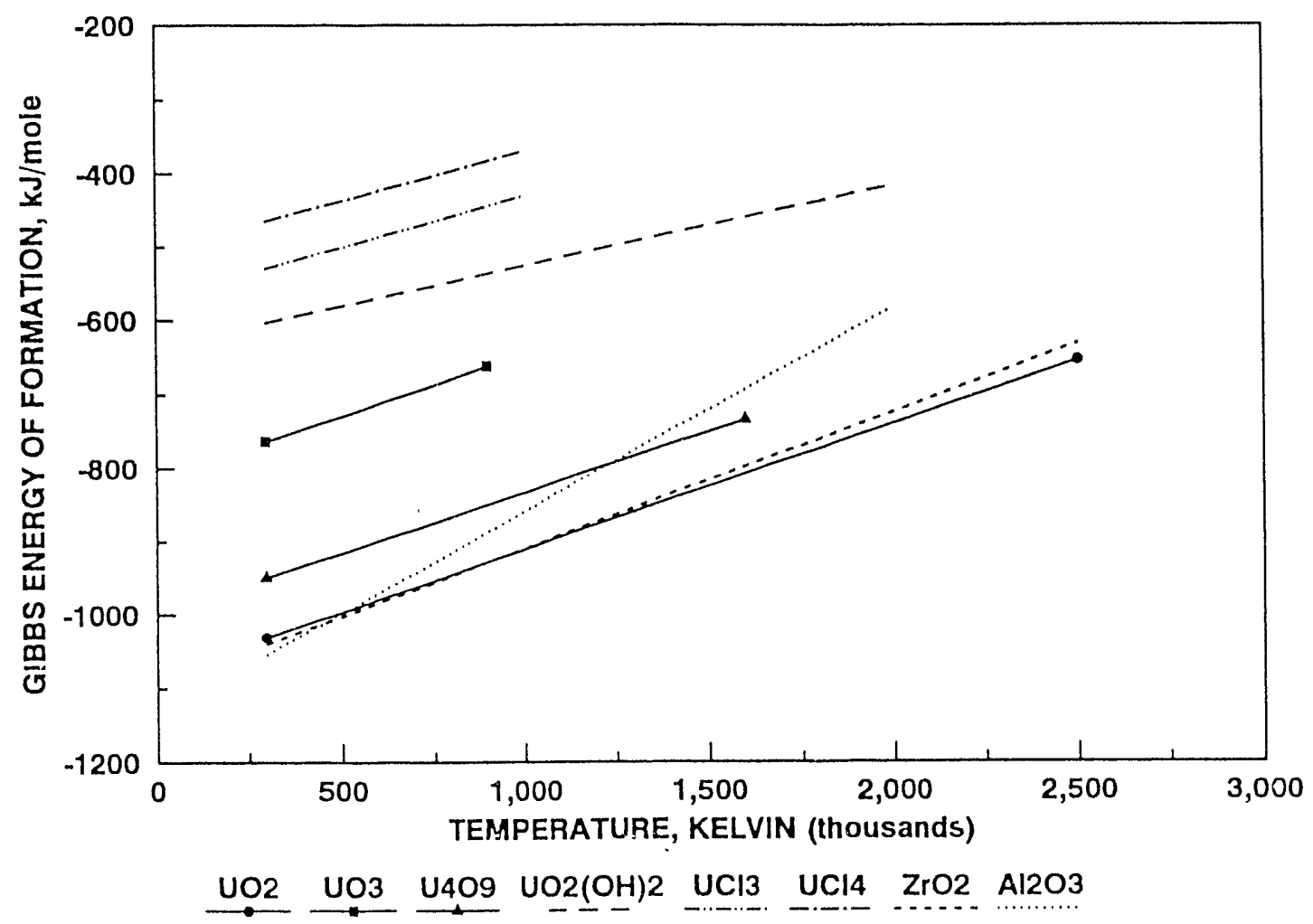

Figure 10. Ellingham diagrams lor aluminum oxide, zirconium oxide and uranium compounds, $\mathrm{kJ} /$ mole of oxygen, $\mathrm{O}_{2}$, or chlorine, $\mathrm{Cl}_{2}$.

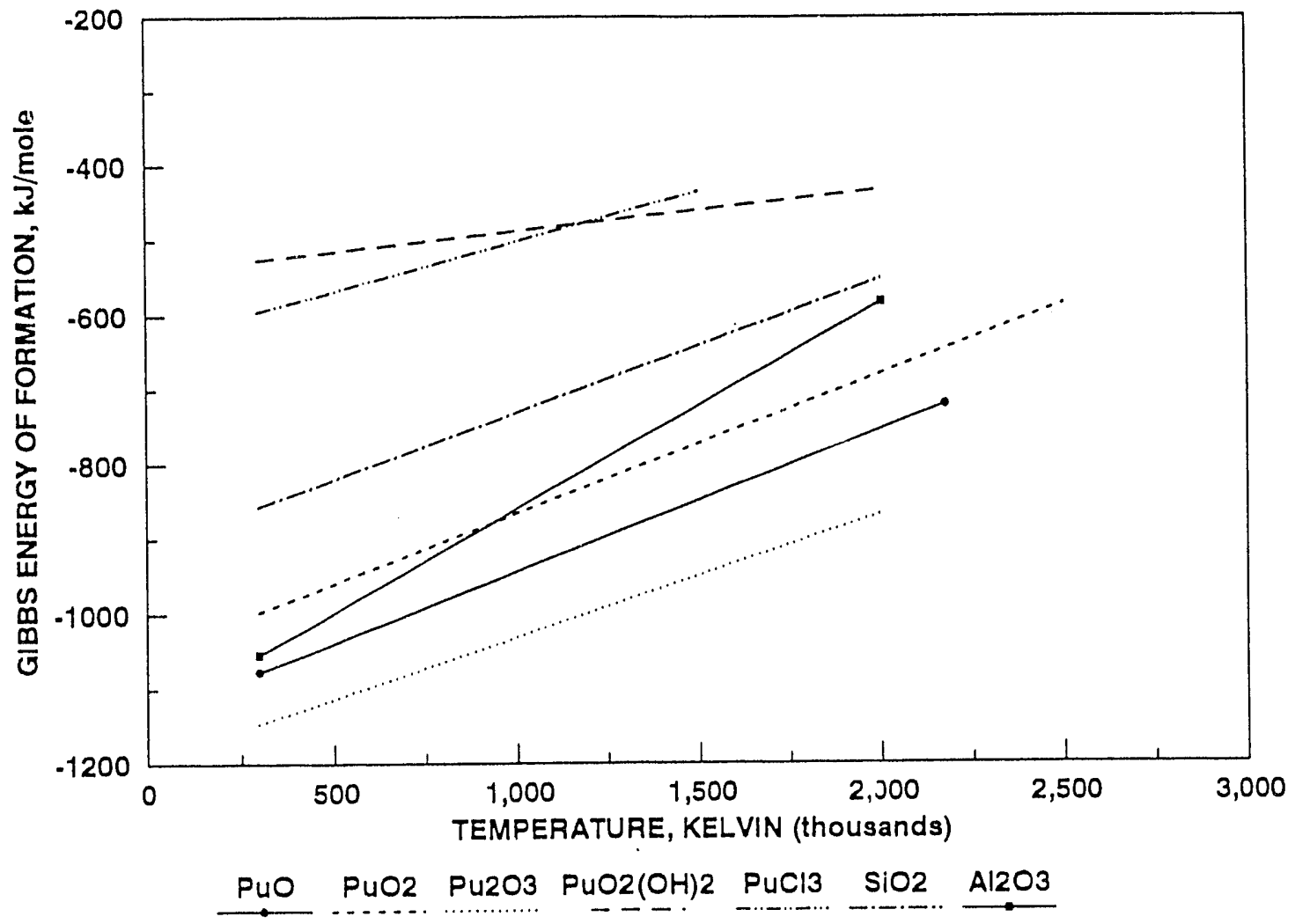

Figure 11. Ellingham diagrams for aluminum oxide, silicon dioxide, and plutonium compounds, $\mathrm{kJ} /$ mole of oxygen, $\mathrm{O}_{2}$, or chlorine, $\mathrm{Cl}_{2}$. 


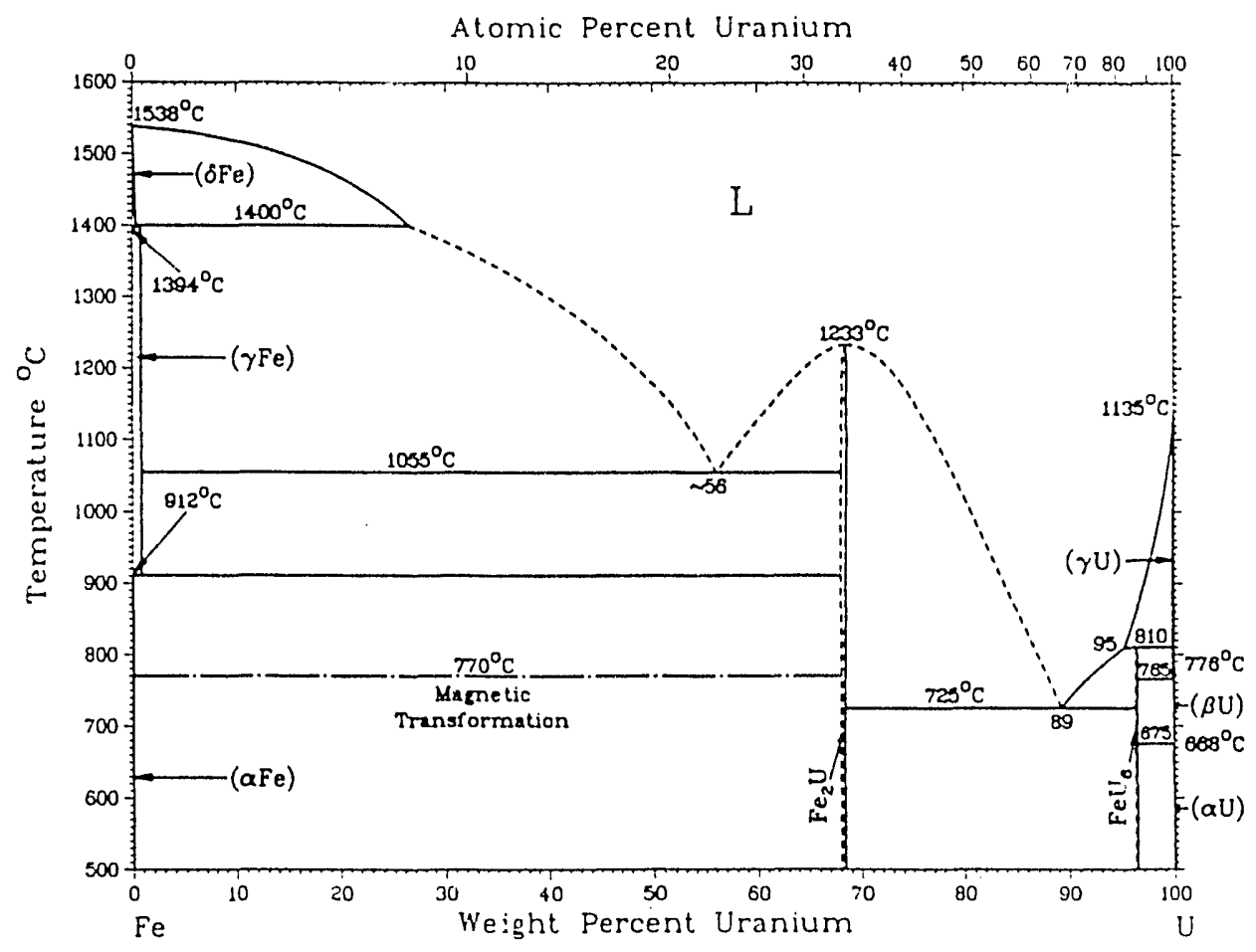

Figure 12. Temperature-composition diagram for the iron-uranium system.

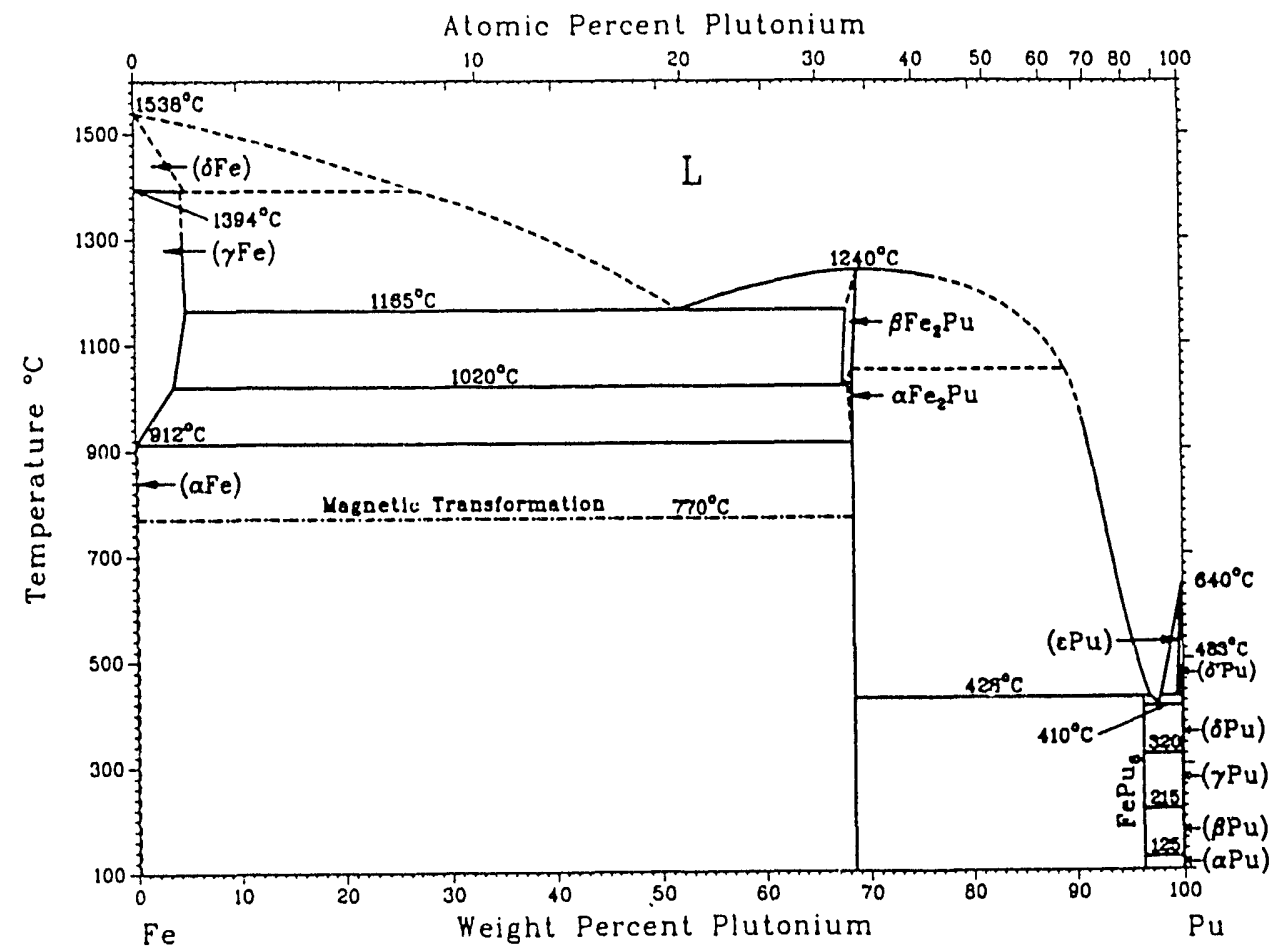

Figure 13. Temperature-composition diagram for the iron-plutonium system. 
intermetallic compounds such as $\mathrm{Fe}_{2} \mathrm{U}$ and $\mathrm{Fe}_{2} \mathrm{Pu}$ can form. If these intermetallic compounds form, they would be expected to be present as separate phases in iron alloys containing uranium and plutonium if the melt was cooled slowly into the solid phase. Slow cooling would be expected if a large mass of metal and slag were formed, as in ISV. It is conceivable that the higher specific gravity intermetallic compounds could settle to form regions of high fissile material concentration. Because it is thermodynamically favorable for large crystals to grow from smaller crystals, it might be possible for locally high concentrations of the intermetallic phases to form without significant settling in the molten mass. (In fact, this slag-metal separation is the basis smelting iron, copper, and other metals, from their ores and for the fire assay of gold and silver ores.)

Processing of spent nuclear luel to separate useful isotopes from waste material is producing an increasing accumulation of low-level contaminated metals (LLCM) containing a variety of radioactive contaminants, including isotopes of plutonium and other transuranics (TRUs). This in turn, has led to a need for information regarding the distribution of radionuclides between slags and metals, similar to the need expressed for ISV systems. Recent experimental work dealing with this problem has been definitive in terms of the melting parameters as a function of composition. These results may be applicable here, even though none of the recent works have dealt with decontamination of LLCM on a production scale. A short review of the experimental protocols and results are given below.

In some slag-metal distribution studies, $\mathrm{UO}_{2}$ has been used as a surrogate for $\mathrm{PuO}_{2}{ }^{11}$ because of very similar chemical behaviors in the environment produced by melt-refining. $\mathrm{UO}_{2}$ is a major constituent in Pit 9; however, TRUs are present in very small amounts. Recent studies compared the effectiveness of various slag compositions, slag-refractory interactions, melt temperatures and times, and distribution of the isotopes as a result of refining processes. In all instances involving the melting of scrap, a major uncertainty is the scrap assay, as no method has yet been devised to sample heterogeneous scrap and obtain reliable and accurate values for the isotope content. This is analogous to the problem of sampling ores to obtain a reliable value for the precious metal content. For the sake of experimental accuracy, adding a known quantity of the contaminant to an uncontaminated heat of metal is the preferred approach.

Experimental metal decontamination programs at Argonne National Laboratory $(A N L)^{12,13}$ and Oak Ridge National Laboratory (ORNL) ${ }^{14,15,16}$ investigated the removal of uranium, plutonium, and americium from ferrous and nonferrous melts using small (50 to 500 g) heats and benchscale equipment. These studies investigated, in some detail, the thermodynamics of the systems, slag compositions, slag-melt interactions, slag-refractory interactions, extraction ratios, etc., with emphases in these studies on reducing the volume of material requiring disposal, converting scrap into a readily assayable form, and reducing the mobility of the contaminants rather than attempting to decontaminate to the extent that the material was suitable for recycle. These studies were designed to lead to processes suitable for scaling up to treat the ever-increasing volumes of accumulated contaminated scrap and permit maximum utilization of shallow land burial with possible subsequent retrieval. If the total TRU content could be reduced to $<10 \mathrm{nCi} / \mathrm{g}$ (equivalent to about $0.1 \mathrm{ppm} \mathrm{Pu}$ ) or less, the potential hazards would be reduced to the extent that retrievable shallow land burial would not be required and the metal castings could be disposed of in commercial landfills without concern for retrievability according to the regulations in effect at the time of burial. No figure is presently available for TRU concentrations considered to be "below regulatory concern," which would 
enable sale of decontaminated ingots for recycling through commercial scrap channels. (The trivial unit of parts per million, "ppm," and parts per billion, "ppb," are equivalent to $\mathrm{mg} / \mathrm{kg}$ and $\mu \mathrm{g} / \mathrm{kg}$, respectively. While the latter units are consistent with the International System of Units [Le Systeme International D' Unites (SI)], ppm and $p p b$ are used here to be consistent with those reported in the cited literature.)

The ANL program used a high-temperature furnace with a tungsten mesh resistance element that would enable the charge to be heated $10,1,800^{\circ} \mathrm{C}$ in "any desired atmosphere" (presumably excluding those containing any oxygen; otherwise, the tungsten element would be destroyed). The furnace was evacuated and backfilled to an absolute pressure of $400 \mathrm{~mm} \mathrm{Hg}$ with dry helium, and the crucible contents were heated to $1,500^{\circ} \mathrm{C}$ and held at that temperature for $1 \mathrm{~h}$. The melts were allowed to solidify in their crucibles, and the resulting ingots and slags were analyzed by autoradiography and/or a fission track analysis technique. TRU contents as low as $0.002 \mathrm{ppm}$ of ${ }^{239} \mathrm{Pu}$ equivalent could be detected by autoradiography, while the detection limit for $\mathrm{Pu}$ and $\mathrm{Am}$ using aqueous dissolution and radiochemical determination was $0.001 \mathrm{ppb}$. The fission track analysis technique also exhibited excellent scnsitivity (to $0.04 \mathrm{ppb} \mathrm{Pu}$ ). The radıgraphy and fission track techniques would pinprint localized concentrations, while the dissolution technique would provide information on the average concentration in the bulk sample.

Most of the melts in the ANL study were performed using $200 \mathrm{~g}$ of mild steel with about 20 $\mathrm{g}$ of slag, or a slag/metal ratio of 0.10 . Alumina crucibles of $100 \mathrm{~mL}$ were used. Melts were contaminated with $400 \mathrm{ppm} \mathrm{Pu}$ (as $\mathrm{PuO}_{2}$ ), although as much as $1.4 \%(14,000 \mathrm{ppm}$ ) Pu was added in one instance. The $\mathrm{PuO}_{2}$ was added to a cavity machined into the bottom of the sample to be melted, which was then sealed with a metal plug or blended with the slag so that the slag would contaminate the melt. No differences in results were noted that could be traced to the method of adding the $\mathrm{PuO}_{2}$. A majority of the melts used a borosilicate slag, ${ }^{a}$ but $\mathrm{CaSiO}{ }_{3}$ and $\mathrm{CaMgSi}_{2} \mathrm{O}_{6}$ slags were used also. The results of this effort were similar to those achieved with the production-scale melting campaigns to reduce uranium and radium in contaminated scrap, in that the contaminants in the steel were reduced to very low levels and were concentrated in the slags. It was interesting to note that the Pu remaining in the ingots was concentrated at or near the ingot surface, possibly as adthering or entrained slag, or in nonmetallic inclusions in the ingot interior. Except for the Pu content, no analysis of the inclusions was given. However, it may be assumed that the composition of the inclusions was fairly close to that of the slag. In some instances, the Pu was concentrated in "clusters" within the ingot. The nature of these clusters was not clearly defined, but it was speculated that they resulted from precipitation of $\mathrm{PuO}_{2}$, which may have had a finite solubility in the molten steel. Where no inclusions or clusters were found, the Pu content of the metal was reported to be as low as $0.04 \mathrm{ppb}$. The dissolution and counting technique showed higher Pu contents than the autoradiography or fission track method on the metal matrix of the same samples, because the dissolution technique averaged in the inclusions, clusters, and any other casting defects in which Pu may have been concentrated.

In cases where more than $400 \mathrm{ppm} \mathrm{Pu}$ was added to the melt, the Pu content and distribution in the ingot were about the same, even when the $\mathrm{Pu}$ additions ranged between 660

a. A Dow Corning 7740 glass, $81.0 \% \mathrm{SiO}_{2}, 13.0 \% \mathrm{~B}_{2} \mathrm{O}_{3}, 4.0 \% \mathrm{Na}_{2} \mathrm{O}, 2.0 \% \mathrm{Al}_{2} \mathrm{O}_{3}$, and $0.5 \% \mathrm{~K}_{2} \mathrm{O}$, by weight. 
and $13,700 \mathrm{ppm}$. These melts weighed only $11-13 \mathrm{~g}$. The ANL reports did not specify how the Pu was added to these small melts, but it seems likely in these cases that the Pu was added to the slag and allowed to equilibrate with the molten steel rather than being sealed into the bottom of the cold metal charge as was done with the $200 \mathrm{~g}$ melts. In theory, the end result should have been the same; however, complications often occur in practice that are not accounted for by assumptions in the theory.

"Staged melting" was performed on one heat where portions of two previously melted ingots were remelted using a clean slag. The result of this experiment was an even greater reduction in $\mathrm{Pu}$ content. The initial content of the charge was reported as "about $0.1 \mathrm{ppm}$ " $\mathrm{Pu}$, while the ingot resulting from this melt averaged $0.002 \mathrm{ppm}$ Pu. Based on what was reported previously, the cleanup must have resulted from a signilicant reduction of $\mathrm{Pu}$-containing inclusions, since the dissolution and counting technique employed for analysis includes the Pu contained in these defects. It is possible that a similar result could have been obtained by a longer holding time in the crucible to allow time for the oxide particles suspended in the melt to coalese and float into the slag. This is more easily done in the resistance furnace employed for this work, because the melt agitation developed by eddy currents during induction heating is absent and only convection currents are operative. The inclusions still trapped in the first melt had an additional hour to float to the surface in the second melt. The total melting time for both heats of the double melt was $2 \mathrm{~h}$. Two other single melts held for this much time under a boro-silicate slag yielded similarly low Pu contents, leading to a conclusion that longer holding times may be nearly as effective as staged melting.

Copeland and coworkers at ORNL conducted experiments similar to those performed at ANL, but studied a wider range of metals and slags and relied more heavily on a thermodynamic approach to metal-slag interaction. The ORNL study used $\mathrm{UO}_{2}$ and $\mathrm{PuO}_{2}$ as contaminants, adding them to the flux and assuming that equilibration during melting would produce the same result as would adding it to the metal charge. Both mild steel and stainless steel (type unspecified) were melted, with induction being the primary melting method. Metal weights between 50 and $500 \mathrm{~g}$ were employed, with $100 \mathrm{~g}$ melts predominating. Flux was added so that it equaled 10 percent (5\% in a few instances) of the metal weight, and $\mathrm{UO}_{2}$ or $\mathrm{PuO}_{2}$ was thoroughly mixed with the flux so that it would be equivalent to $500 \mathrm{ppm}$ ( $\approx 440 \mathrm{ppm} \mathrm{U}$ or $\mathrm{Pu}$ ) in the metal. Melting times were $1 / 2$ to $1 \mathrm{~h}$, melts were allowed to solidify in the crucible, and ingots assaying between 0.01 to $0.1 \mathrm{mg} / \mathrm{kg} \mathrm{U}$ and $<1 \mathrm{ppm}$ Pu were obtained for both mild and stainless steel melts. The results for mild steel were not as low as those obtained by ANL, even though similar dissolution and counting analytical techniques were used. Halving the slag weight had no apparent effect on the refining capability, but double melting, i.e., melting-freezing-melting-freezing, reduced the $\mathrm{Pu}$ level in the metal phase to $0.1 \mathrm{ppm}$, which was a goal of their effort. The ORNL study concluded that halving the slag weight and double-refining was an effective approach and reduced the quantity of waste requiring disposal.

If uranium or plutonium were found in metallic iron, three obvious mechanisms could be postulated. One mechanism is to form solid solutions of uranium or plutonium. In the iron-rich phase, this could occur when the concentration of uranium or plutonium was very low. A second mechanism of incorporating uranium or plutonium in iron is as an intermetallic compound forming a separate phase; it is conceivable that the intermetallic compound could be present in solid solution at very low concentrations. The third mechanism of incorporating uranium or 
plutonium in iron is as slag inclusions of the oxides. The presence of slag inclusions in metal melts is common, and care must be exercised to minimize their inlluenee on the linal metallic product. Slag inclusions in contact with the external slag would be dissolved into the slag phase. Considerations of the possibility of slag inclusions would be especially important in drawing conclusions from slag-metal distribution data such as that noted in Referenecs 10-12.

The distribution of uranium between a slag and iron has been studied in terms of the distribution coefficient. ${ }^{11,12}$ The distribution coefficient may be defined as the concentration of a solute in the slag phase divided by the concentration in the metal. This implies that the solute uranium is in true solution and not present as a slag inclusion. For example, the distribution of uranium between the oxide phase (slag) and iron metal is given by the partition coefficient, $\mathrm{K}_{\mathrm{d}}$, or distribution cocfficient, $\mathrm{D}$, where:

$$
\mathrm{K}_{\mathrm{d}}=\mathrm{D}=\text { uranium concentration in slag/uranium concentration in iron }
$$

A more accurate relationship would involve the thermodynamic activity of the solute species in the metal and slag phases. At equilibrium, the activity of the solute species in the two phases will be equal, even though their analytical concentrations will not. This rellects the difference in chemical potential of the species in their respective environments.

Seitz et al. ${ }^{12}$ reported distribution coefficient data for plutonium in mild steel, $D=2 \times 10^{6}$; in stainless steel, $\mathrm{D}=8 \times 10^{6}$; and in nickel, $\left.\mathrm{D}=5 \times 10\right)^{4}$

An important question in this regard is the solubility of uranium and plutonium in iron and in the slag. The amount of plutonium in the waste being considered is small enough that only the low plutonium region of the phase diagrams need to be considered. However, if enriched uranium in oxide form is a major constituent in the waste system, it must be considered more fully. In situations where a solid solution can be formed, the tendency for more dense metals to settle into a separate phase is minimized. Advantage may be taken of this to add slag-making materials that will dilute the fissile naterial. For example, depleted uranium, in the oxide form, could be added to the melt to dilute the fissile material to a concentration lower than that required for criticality. Similar diluents for plutonium may be available that will form solid solutions and thereby reduce the tendency to settle.

Experimental evidence substantiates the idea that uranium and plutonium oxides will preferentially remain in the slag or glass phase rather than be reduced to the metallic state and be dissolved into the molten iron. 


\section{COMPUTER CODES}

There are several eomputer codes available for making equilibrium thermodynamic calculations. These codes were recently reviewed by Bale and Ericksson. ${ }^{17}$ Ericksson developed the SOLGASMIX algorithm for making these types of calculations. This code was subsequently modified by others and has become the basis for several codes. The Generic Mineral Technology Center for Pyrometallurgy (supported as a center of excellence by the U.S. Bureau of Mines) at the Department of Metallurgical Engineering, University of Missouri, Rolla (UMR) has been particularly active in this area and has recently issued Version 4.22 of STEPSOL. The program is capable of handling up to 14 input species, 84 output species, and 19 phases. This version was used in making the free energy mininization calculations reported here.

Besmann ${ }^{18}$ at ORNL also modilied SOLGASMIX and issued a version named SOLGASMIX-PV. Besmann's modification uses the ideal gas law to permit calculating equilibria at a total gas volume with variable total pressure. Sheldon, ${ }^{19}$ also at ORNL, developed SOLGASMIX-PV for the IBM-PC. This program is capable of handling 10 elements, 99 substances, and 10 mixtures. The gas phase is considered to be a mixture. This version requires a math eo-processor in the $\mathrm{PC}$ due to the large number of computations made during program execution. A FORTRAN compiler is also required to compile and link the programs.

In the chemical industry, a process was developed for production of sodium carbonate from sodium chloride and calcium carbonate. The process is relatively complicated, with intermediate products and recycled reagents. This is the Solvay process. Rudd and his students ${ }^{19}$ developed algorithms to model the Solvay process and explore additional process options. The Chemical Sciences Group at EG\&G Idaho, Inc., made further developments ${ }^{20}$ in these models for the High-Temperature Heat Pump program.

An analysis of the algorithms in STEPSOL will be made to provide the necessary documentation for the ISV program. This analysis will be reported separately.

The pyrometallury eenter at UMR has also developed a code for simulating reaction kinetics between metal, slag, and gas phases. The program assumes equilibrium at the interface and calculates the rate of mass transfer of species to or from the interface. This program, RSMAK, was not used as part of the present ISV evaluation. It may be uscful in making reaction kinetics studies in the ISV system, if the present task is extended into that area. 


\section{THERMODYNAMIC DATA BASES}

There are a number of large data bases available for making equilibrium thermodynamics calculations. Those considered in this study are discussed below.

\section{JANNAF}

The JANNAF (Joint Army, Navy, Air Forec) data base ${ }^{21}$ is large and contains a significant amount of useful information. Much of the data in STEPSOL was abstracted from the JANNAF data base.

\section{BARIN and KNACKE}

The Barin and $\mathrm{Knacke}^{22}$ data base covers more soil-like materials than the JANNAF tables and is largely based on the earlier work of Kubascheswki, Alcock, and Evans. ${ }^{23}$

\section{U.S. BUREAU OF MINES}

There was a long-term effort at the U.S. Bureau of Mines Research Center at Albany, Oregon (ALRC), to develop thermodynamic data bases for making metallurgical calculations. Earlier ALRC data compilations have been widely used. Compilations of data for oxides ${ }^{24}$ and halides ${ }^{4}$ have been published and are available for reference. Selected compounds from these tables could be entered into the programs to supplement the Barin and Kanake or JANNAF data bases.

\section{U.S. GEOLOGICAL SURVEY}

Thermodynamic data for making calculations of the geochemical conditions in rock formations have been collected by the U.S. Geological Survey (USGS). ${ }^{25}$ These data are not as extensive as the JANNAF, Burcau of Mines, or the Barin and Kanake data bases. Limited data from these sources have been included in the STEPSOL computer program.

\section{TEXAS A\&M UNIVERSITY}

This data base is largely devoted to hydrocarbon and similar petroleum materials. ${ }^{20}$ There may be some halocarbon data in these tables that could be used for making calculations involving reactions of chlorocarbons that have been dumped in the INEL waste area.

A detailed evaluation of the data in the above thermodynamic data bases is beyond the scope of the present task. 


\section{BASELINE COMPOSITION}

The nominal composition of the wastes being considered were extracted from Appendix A of "Modeling Requirements for ISV."' Data in the tables of composition for Pit 9 are given in $\mathrm{m}^{3}$, in $\mathrm{kg}$, or both. The convers:on factor between $\mathrm{kg}$ and metric tons is 1,000 . The metric ton is termed a tonne $(t)$. This term is a commonly used in engineering, but it is deprecated by SI. ${ }^{27}$ The conversion between specilic gravity, with respect to water, or density in $\mathrm{g} / \mathrm{mL}$ to $t / \mathrm{m}^{3}$ is suggested by

$$
1 \mathrm{t}=10^{6} \mathrm{~g}
$$

and

$$
1 \mathrm{~m}^{3}=10^{6} \mathrm{~mL}
$$

Comparing these two equations yields

$$
1 \mathrm{t} / \mathrm{m}^{3}=1 \mathrm{~g} / \mathrm{mL} \text {. }
$$

Thus, merely changing the names of the units suffices to make the conversion.

The STEPSOL computer code is limited to 14 species that can be specified for the input. This limitation requires that many simplifying assumptions be made regarding similarity of species and possible interactions that could give rise to chemicals at low temperatures. For example, rather than specifying both fer ric chloride and hydrochloric acid as inputs, the decision was made to consider hydrolysis products such as hydrochloric acid and iron oxide.

\section{Inorganic Chemicals in Pit 9}

Of the numerous inorganic chemicals identified in Pit 9, only those having large concentrations or particular reactivity are considered in the slag-metal study. Amounts discussed below are listed in Table 1.

There are about $2.3 \mathrm{t}$ of aluminum compounds in Pit 9. For calculational purposes, this is asumed to be present as alunininum oxide, $\mathrm{Al}_{2} \mathrm{O}_{3}$. This was a common insulating material in electrica!ly heated pins simulating nuclear fucl pins in the Semiscale tests, for example. This is in addition to hydrous aluminum oxides noted below.

There are about $24.5 \mathrm{t}$ of barium compouncis in Pit 9. Barium sulfate or barite, $\mathrm{BaSO}_{4}$, is commonly used for high density concretes, such as those used for radiation shielding. For purposes of this analysis, the barium compounds are assumed to be $24.5 \mathrm{t}(0.103 \mathrm{t} \mathrm{mol})$ of barite. In the model, this is considered to be equivalent to $5.8 \mathrm{t}(0.103 \mathrm{tmol})$ of calcium oxide.

There are $0.3 \mathrm{t}(0.0156 \mathrm{t} \mathrm{mol})$ of beryllium in Pit 9 . Beryllium metal is a strong reducing agent and could react with oxides of uranium and plutonium to yicld metallic uranium and 
Table 1. Inorganic components of Pit 9 for modeling purposes.

\begin{tabular}{lclc}
\hline \multicolumn{1}{c}{ Species } & Tonnes & Species & Tonnes \\
\hline $\mathrm{Al2O} 3$ & $2,830.27$ & $\mathrm{KNO} 3$ & $28.25(02)$ \\
$\mathrm{BaSO} 4$ & 24.5 & $\mathrm{~K} 2 \mathrm{O}$ & 618.43 \\
$\mathrm{Be}$ & 0.3 & $\mathrm{Li}$ & 6.2 \\
$\mathrm{C}$ & 85.2 & $\mathrm{MgO}$ & 56.8 \\
$\mathrm{CO} 2$ & 35.0 & $\mathrm{Mn}$ & 1.4 \\
$\mathrm{CaO}$ & $2,489.6$ & $\mathrm{Na}$ & 12.74 \\
$\mathrm{Cr}$ & 57.3 & $\mathrm{Na} 2 \mathrm{O}$ & 327.4 \\
$\mathrm{Cr} 203$ & 1.7 & $\mathrm{NaNO}$ & $64.74(02)$ \\
$\mathrm{Fe}$ & 543.8 & $\mathrm{Ni}$ & 29.4 \\
$\mathrm{Fe} 3 \mathrm{O} 4$ & 998.4 & $\mathrm{PbO}$ & 7.0 \\
$\mathrm{Fe} 2 \mathrm{O} 3$ & 37.46 & $\mathrm{SO}$ & 0.72 \\
$\mathrm{FeCl} 3$ & 2.7 & $\mathrm{Si}$ & 0.8 \\
$\mathrm{H} 2$ & 0.06 & $\mathrm{SiO} 2$ & $17,206.7$ \\
$\mathrm{H} 2 \mathrm{O}$ & 132.04 & $\mathrm{Zr}$ & 17.4 \\
$\mathrm{Hg}$ & 17.7 & $\mathrm{Other}$ & 262.9 \\
& & & \\
\hline
\end{tabular}

plutonium. There is more than enough beryllium present to reduce all of the plutonium oxides to metallic plutonium. For modeling purposes, the beryllium is assumed to be $\mathrm{BeO}$ and in the model is considered to be equivalent to $0.87 \mathrm{t}(0.0156 \mathrm{t} \mathrm{mol})$ of calcium oxide.

There are $58.8 \mathrm{t}$ of calcium silicate, $3 \mathrm{CaO} \cdot \mathrm{SiO}_{2}$, in $\mathrm{Pit} 9$. This is a composition similar to some constituents in soil and cement and is lumped with those materials for this analysis. The calcium silicate is equivalent to $43.3 \mathrm{t}$ of $\mathrm{CaO}$ and $15.5 \mathrm{t}$ of $\mathrm{SiO}_{2}$.

There are $1.7 \mathrm{t}$ of chromium compounds in Pit 9. Chromates were widely used at the INEL for corrosion control in recirculating water systems. The chromates in Pit 9 could be reduced to metallic chromium by appropriate reducing agents. For analysis purposes, the chromium is assumed to be present at $1.7 \mathrm{t}(0.011 \mathrm{t} \mathrm{mol})$ of chromium oxide, $\mathrm{Cr}_{2} \mathrm{O}_{3}$. This is equivalent to 1.14 $\mathrm{t}$ of chromium, or, for the model, $1.96 \mathrm{t}$ of nickel.

Pit 9 contains $2.7 \mathrm{t}$ of iron compounds. Since carbon steel and hydrous iron oxides are listed separately, the iron compounds are considered chlorides. Iron(III) chloride is commonly used in 
water treatment as a coagulating agent; it is also used to etch printed circuit boards. In the presence of reducing agents, it is reduced to iron(II); in the presence of air, iron(II) is oxidized to iron(III). Thus, modeling the iron compounds as iron(III) chloride is a reasonable compromise. The iron is considered to be $2.7 \mathrm{t}$ of iron(III) chloride, $\mathrm{FeCl}_{3}$. For the model, this is equivalent to $1.329 \mathrm{t}$ of hematite and $1.82 \mathrm{t}$ of hydrogen chloride (this hydrogen chloride is made equivalent to carbon tetrachloride and water in the model); $0.449 \mathrm{t}$ of water is consumed.

Pit 9 contains $7 \mathrm{t}$ of lead compounds. In the absence of further information, this lead is presumed to be present as $7 \mathrm{t}(0.03 \mathrm{t} \mathrm{mol})$ of lead oxide, $\mathrm{PbO}$, also termed litharge. This compound is stable at process temperatures and is modeled as $1.76 \mathrm{t}(0.03 \mathrm{t} \mathrm{mol})$ of calcium oxide.

There are $6.2 \mathrm{t}$ of lithium compounds in Pit 9. Lithium is a reactive metal, similar to sodium in its chemical properties. Experiments using liquid metals, including liquid lithium, have been conducted at the INEL. However, for analysis purposes, the lithium is presumed to be present as $2.208 \mathrm{t}$ mol of lithium oxide, $\mathrm{Li}_{2} \mathrm{O}$. This is modeled as being equivalent to $12.87 \mathrm{t}(0.208 \mathrm{t}$ mol $)$ of sodium oxide.

Pit 9 contains $87.5 \mathrm{t}$ of asbestos. Even though thermodynamic data for asbestos are available, its stoichiometry is $2 \mathrm{MgO}^{-\mathrm{SiO}_{2}}$, similar to soil and cement constituents, and will be modeled as magnesium and silicon oxides. The asbestos in Pit 9 is equivalent to $56.5 \mathrm{t}$ of $\mathrm{MgO}$ and $30.9 \mathrm{t}$ of $\mathrm{SiO}_{2}$. For the model, the magnesium oxide is considered to be equivalent to $78.5 \mathrm{t}(1.40 \mathrm{tmol})$ of calcium oxide.

There are $17.7 \mathrm{t}$ of mercury in Pit 9 . Mercuric nitrate has been used to promote dissolution of aluminum fuel plates. This material should have been contained in the high-level waste materials from fuel reprocessing and should not be in Pit 9. Metallic mercury has also been used at the INEL. For thermodynamic evaluations, all of the mercury is assumed to be present as the metal. Mercury oxides are quite unstable and decompose to liberate oxygen and elemental mercury at 900 to $1,000 \mathrm{~K}$; thus, they may serve as an oxygen source and as oxidizing agents. Further, the boiling point of mercury is about $630 \mathrm{~K}\left(357^{\circ} \mathrm{C}\right)$, indicating that the mercury should leave the hot zone of the molten mass of waste, probably during the heatup stage. Mercury is not included in the thermodynamic model.

Pit 9 contains $80.2 \mathrm{t}(0.793 \mathrm{t} \mathrm{mol})$ of potassium nitrate and $172 \mathrm{t}(2.024 \mathrm{t}$ mol $)$ of sodium nitrate. Both of these compounds are strong oxidizing agents and are commonly used as the oxidant in black gun powder. Upon strong heating, they decompose irreversibly into oxygen and nitrite salt, thus:

$$
2 \mathrm{NaNO}_{3}===>2 \mathrm{NaNO}_{2}+\mathrm{O}_{2}
$$

With heavy metal nitrates, e.g., copper nitrate, a reaction such as:

$$
2 \mathrm{Cu}\left(\mathrm{NO}_{3}\right)===>2 \mathrm{CuO}+4 \mathrm{NO}_{2}+\mathrm{O}_{2}
$$

could be expected. If the hot nitrates come into contact with organic wastes, such as ion exchange resins, paper, rags, or wood, there is a strong possibility that very rapid oxidation could 
occur resulting in a deflagration or explosion. Thermodynamic data are available for both nitrates and nitric oxide but not for the nitrite salts. The data show that the nitrates have large negative Gibbs energies of formation, and the nitric and nitrous oxides have large positive Gibbs energies of formation. This indicates that modeling the nitrates in a Gibbs energy minimization study will not reflect the above equations. The first approximation is to model the nitrates as equivalent amounts of sodium oxide and oxygen. This yields $27.60 \mathrm{t}$ of oxygen from the potassium nitrate and $64.75 \mathrm{t}$ of oxygen from the sodium nitrate, a total of $92.35 \mathrm{t}$ of oxygen that could be released during the melting process. The sodium and potassium nitrates are considered to be equivalent to $109.8 \mathrm{t}(2.8165 \mathrm{t} \mathrm{mol})$ of sodium oxide.

There are $17.4 \mathrm{t}$ of zirconium chemicals in Pit 9. Zirconium metal is the major constituent in zircaloy, and zirconium oxide is a widely used insulating material. There may be other zirconium compounds in the wastes, but the assumption here is that all of the zirconium is present as zirconium oxide, $\mathrm{ZrO}_{2}$. In the melt, it would be expected to form zirconium silicate; and for this reason, it is modeled as $7.43 \mathrm{t} 0.133$ ( $\mathrm{t}$ mol) of calcium oxicle.

\section{Other Miscellaneous Chemicals in Pit 9}

There are $60.84 \mathrm{~m}^{3}$ of hydrated oxides in Pit 9. These are identified as hydrated oxides of aluminum, iron, silicon, magnesium, plutonium, and americium. In the absence of a more accurate analysis, two assumptions were made. First, these oxides could be represented on average as about half aluminum oxides and half iron oxides. Second, the radioisotopes are accounted for in the catagory "Radionuclides in Pit 9." Aluminum hydroxide, $\mathrm{Al}(\mathrm{OH})_{3}$, was selected as the average hydrous aluminum oxide in Pit 9 . Iron(III) hydroxide, $\mathrm{Fe}(\mathrm{OH})_{3}$, was selected as the average hydrous iron oxide present. Thermodynamic data are available for both compounds.

As another assumption, the bulk density of these hydrous oxides was taken to be similar to soil, about $100 \mathrm{lb} / \mathrm{ft}^{3}$, or $1.6 \mathrm{t} / \mathrm{m}^{3}$. The mass of this waste is $97.5 \mathrm{t}$ of mixed hydrous oxides and yields $48.75 \mathrm{t}$ of aluminum hydroxide and $48.75 \mathrm{t}$ of iron(III) hydroxide. Both of these compounds are unstable as temperature rises. For example, analytical methods for gravimetric determination of these metals rely on their instability. ${ }^{28}$ Hydrous iron oxide decomposes in the range of 1,100 to $1,300 \mathrm{~K}$ to form $\mathrm{Fe}_{2} \mathrm{O}_{3}$ (see Figure 3 for a phase diagram showing the relative stability of iron-oxygen compounds as a function of temperature). Hydrous aluminum oxide decomposes to gamma-aluminum oxide at approximately $600 \mathrm{~K}$. Because of these instabilities, these hydrous oxides are modeled as their respective oxides and water. The $48.75 \mathrm{t}$ of iron(III) hydroxide becomes $36.4 \mathrm{t}$ of $\mathrm{Fe}_{2} \mathrm{O}_{3}$ and $12.3 \mathrm{t}$ of water. The $48.75 \mathrm{t}$ of hydrous aluminum oxide becomes $31.9 \mathrm{t}$ of $\mathrm{Al}_{2} \mathrm{O}_{3}$ and $16.8 \mathrm{t}$ of water.

Pit 9 contains $13.13 \mathrm{~m}^{3}$ of sodium and sodium compounds. Numerous tests involving sodium-cooled reactors and sodium-potassium $(\mathrm{NaK})$ cooled reactors have been performed at the INEL; much of the NaK was hydrolyzed with water to form hydroxides, for example. Since there is little information regarding the subject material, it is modeled as sodium hydroxide. Sodium hydroxide has a density of $2.13 \mathrm{t} / \mathrm{m}^{3}$. This yields $27.97 \mathrm{t}(0.35 \mathrm{t} \mathrm{mol})$ of sodium hydroxide, which is equivalent to $21.68 \mathrm{t}(0.36 \mathrm{t} \mathrm{mol})$ of sodium oxide and $6.29 \mathrm{t}(0.35 \mathrm{t} \mathrm{mol})$ of water. 
There are $12.68 \mathrm{~m}^{3}$ of miscellaneous solutions, identified as $10 \%$ solutions of sodium and potassium nitrates. In the absence of other data, the assumption is made that these are mixed; and each $t$ of solution contains sodium and potassium nitrates in equal amounts, i.e., a $5 \%$ solution of each compound. The density of these $5 \%$ solutions is $1.03 \mathrm{t} / \mathrm{m}^{3}$. This yields $13.06 \mathrm{t}$ of solution, containing $0.65 \mathrm{t}$ of each nitrate and $11.67 \mathrm{t}$ of water. As noted above for the potassium and sodium nitrates, these nitrates can be expected to decompose on heating to yield oxygen and nonreactive nitrite salts. The potassium nitrate would yield $0.44 \mathrm{t}(0.0052 \mathrm{t}$ mol $)$ of potassium nitrite, equivalent to $0.22 \mathrm{t}(0.0052 \mathrm{tmol})$ of sodium hydroxide and $0.22 \mathrm{t}$ of oxygen. The sodium nitrate would yield $0.41 \mathrm{t}(0.0059 \mathrm{t}$ mol) of sodium nitrite, equivalent to $0.24 \mathrm{t}(0.0059 \mathrm{t} \mathrm{mol})$ of sodium hydroxide and $0.24 \mathrm{t}$ of oxygen for a total of $0.46 \mathrm{t}$ of oxygen from these solutions.

Pit 9 contains $4.75 \mathrm{~m}^{3}$ of acids, identified only as $\mathrm{HCl}, \mathrm{HF}$, etc. For purposes of this analysis, the "acid" is considered to be hydrochloric acid. Concentrated hydrochloric acid has a specific gravity of $1.19\left(1.19 \mathrm{t} / \mathrm{m}^{3}\right)$ and a concentration of approximately $12.1 \mathrm{~N}(.4412 \mathrm{~kg} / \mathrm{L}$ or $\left.0.4412 \mathrm{t} / \mathrm{m}^{3}\right)$ resulting in $2.10 \mathrm{t}(0.0133 \mathrm{t} \mathrm{mol})$ of hydrogen chloride [in the model, this hydrochloric acid is made equivalent to $2.05 \mathrm{t}(.00666 \mathrm{tmol})$ of carbon tetrachloride and $0.48 \mathrm{t}$ $(0.0266 \mathrm{t} \mathrm{mol})$ of water].

There are $3.25 \mathrm{~m}^{3}$ of caustic compounds (listed as $\mathrm{NaOH}$, etc.) in Pit 9. For this analysis, these materials are considered solid $\mathrm{NaOH}$. Sodium hydroxide has distinctly different slag-making properties compared to sodium carbonate, for example. ${ }^{29,30}$ Sodium hydroxide has a density of $2.13 \mathrm{t} / \mathrm{m}^{3}$, yielding $6.9 \mathrm{t}(0.086 \mathrm{t} \mathrm{mol})$ of $\mathrm{NaOH}$, equivalent to $5.35 \mathrm{t}(0.086 \mathrm{tmol})$ of sodium hydroxide and $0.24 \mathrm{t}$ of water.

Pit 9 contains $187.7 \mathrm{t}$ of paper, rags, and wood. These are cellulose materials, being polymers of glucose. These are more appropriately modeled with the other organic materials, such as oils, alcohols, and chlorinated solvents, noted below.

There are $72.8 \mathrm{t}$ of concrete and asphalt in Pit 9. Without other identification, these are modeled as half concrete and hall asphalt from sources such as facility decontamination and decommissioning. Concrete used at the INEL is typically $15.8 \%$ cement, $7.9 \%$ water, $47.4 \%$ rock, and $29.0 \%$ sand and has a density of 2.2 to $2.3 \mathrm{t} / \mathrm{m}^{3}$. This amounts to $5.7 \mathrm{t}$ of Portland cement (in addition to that identified below), $2.9 \mathrm{t}$ of water, $17.2 \mathrm{t}$ of rock, and $10.5 \mathrm{t}$ of sand. Concrete formulated by vendors in Idaho Falls consists of quartz and other high silica materials for the aggregate, while concrete formulated at the Central Facilities Area will frequently contain large amounts of basalt and calcareous materials in the aggregate. This aggregate is assumed to be $27.7 \mathrm{t}$ of silica, $\mathrm{SiO}_{2}$ for modeling purposes. The $5.7 \mathrm{t}$ of Portland cement has a nominal stoichiometry and (amount) of $\mathrm{K}_{2} \mathrm{O} 0.51 \%(0.03 \mathrm{t}), \mathrm{Na}_{2} \mathrm{O} 0.21 \%(0.01 \mathrm{t}), \mathrm{Al}_{2} \mathrm{O}_{3} 5.6 \%(0.32 \mathfrak{t})$, $\mathrm{CaO} 64.2 \%$ (3.66 t), $\mathrm{MgO} 3.7 \%$ (0.21 t), $\mathrm{Fe}_{2} \mathrm{O}_{3} 2.4 \%$ (0.14 t), $\mathrm{SiO}_{2} 20.7 \%$ (1.18 t), $\mathrm{TiO}_{2} 0.23 \%$ $(0.01 \mathrm{t}), \mathrm{SO}_{3} 1.6 \%(0.09 \mathrm{t})$ and undelined other $0.85 \%(0.05 \mathrm{t})$. The $0.03 \mathrm{t}(0.00032 \mathrm{t} \mathrm{mol})$ of potassium oxide is modeled as $0.00032 \mathrm{tmol}(0.02 \mathrm{t})$ of sodium oxide. The $0.21 \mathrm{t}(0.0052 \mathrm{t} \mathrm{mol})$ of magnesium oxide is modeled as $0.052 \mathrm{t} \mathrm{mol}(0.29 \mathrm{t})$ of calcium oxide. The contributions of titanium oxide and sullur trioxide are not considered in the model.

The asphalt is typically 5 to $6 \%$ asphalt oil and aggregate. Asphalt oil is typically 30 to $40 \%$ petroleum distillate, with the remainder being high carbon solids. This yields $0.73 \mathrm{t}$ of petroleum distillates having about $0.62 \mathrm{t}$ of carbon and $0.11 \mathrm{t}$ of hydrogen. The high carbon solids were 
estimated to be $95 \%$ carbon and 5\% hydrogen, yielding an additional $1.0 \mathrm{t}$ of carbon and $0.06 \mathrm{t}$ of hydrogen. The quantity of hydrogen is small enough to neglect in the model. The aggregate is similar to the concrete aggregate, but it is washed to remove fines. This is modeled as silica, yielding $34.6 \mathrm{t}$ of silica, $\mathrm{SiO}_{2}$.

There are $7.2 \mathrm{t}$ of glass in Pit 9. Without additional information, this is modeled as window glass rather than borosilicate laboratory glassware. Window glass varies considerably in composition, principally in silica, alumina, and soda concentrations. For the present purposes, a nominal stoichiometry and (amount) of $72 \% \mathrm{SiO}_{2}(5.2 \mathrm{t}), 1.3 \% \mathrm{Al}_{2} \mathrm{O}_{3}(0.1 \mathrm{t}), 8.2 \% \mathrm{CaO}(0.6 \mathrm{t})$, $3.5 \% \mathrm{MgO}(0.25 \mathrm{t}), 14.3 \% \mathrm{Na}_{2} \mathrm{O}(1.0 \mathrm{t}), 0.3 \% \mathrm{~K}_{2} \mathrm{O}(0.021 \mathrm{t})$, and $0.3 \% \mathrm{SO}_{3}(0.02 \mathrm{t})$, was used to model the glass. The $0.25 \mathrm{t}(0.0063 \mathrm{t} \mathrm{mol})$ of magnesium oxide is equivalent to $0.35 \mathrm{t}(0.0063 \mathrm{t}$ $\mathrm{mol})$ of calcium oxide. The $0.021 \mathrm{t}(0.00023 \mathrm{t} \mathrm{mol})$ of potassium oxide is equivalent to $0.014 \mathrm{t}$ $(0.00023 \mathrm{t} \mathrm{mol})$ of sodium oxide. The sulfur trioxide is not considered in the model.

Pit 9 contains $16.4 \mathrm{t}$ of graphite. This is modeled as carbon in the present analysis.

Most of the wastes in Pit 9 are contained in 55-gal steel drums. The iron in these drums could be considered as a reducing agent. However, above approximately $900 \mathrm{~K}$, the oxides of carbon are more stable than those of iron; and carbon and carbon monoxide are better reducing agents than metallic iron. The iron will melt, but it will not be a significant reactant in the ISV melt. However, it may be a significant solvent for some molten constituents. There are $326.5 \mathrm{t}$ of carbon steel in Pit 9. This is assumed to be similar to AISI-type 1020 carbon steel, e.g., ASTM A 285, having a nominal composition and (amount) of iron $99.2 \%$ (323.9 $\mathrm{t}$ ), carbon $0.2 \%(0.7 \mathrm{t})$, manganese $0.45 \%$ ( $1.4 \mathrm{t}$, equivalent to $1.5 \mathrm{t}$ of nickel), and silicon $0.25 \%(0.8 \mathrm{t})$.

Pit 9 contains $309.7 \mathrm{t}$ of stainless steel. This is assumed to be similar to AISI-type 304 stainless steel, e.g., ASTM A 240, having a nominal composition and (amount) of iron $72 \%$ $(219.9 \mathrm{t})$, chromium $18.5 \%(57.3 \mathrm{t})$, nickel $9.5 \%$ (29.4 $\mathfrak{t})$, and carbon $0.08 \%(0.3 \mathfrak{t})$. For the analytical model, the $57.3 \mathrm{t}(1.102 \mathrm{tmol})$ of chromium is equivalent to $64.7 \mathrm{t}(1.102 \mathrm{t} \mathrm{mol})$ of metallic nickel.

\section{Soil and Portland Cement}

The soil and Portland cement are listed under "Oxide Compositions of Materials in Pit 9."

During the last glaciation, large amounts of rock were ground into powder by the abrasion of rocks trapped in the moving glacier. Locally, these powders were carried from glacier outflow by water action then deposited onto the Snake River plain by a combination of water and wind action. These sediments are referred to as loess. ${ }^{29}$ The loess has also been mobilized by water and wind action so that the deposits now have both windblown and waterborne characteristics. There is evidence of soil sediments between various lava formations at the INEL. ${ }^{30}$

Weathering of the loess has resulted in changes in the composition of these sediments such that the uppermost layers may have very different compositions from lower layers. In particular, the loess constituents that weather to form calcium carbonate, calcite, and $\mathrm{CaCO}_{3}$ have greatly diminished since they were lain in place. This leaching action and subsequent disequilibrium has resulted in deposition of calcite in the underlying basalt formations, giving the basalt a coating of 
white calcite. These formations are seen, for example, in some road cuts between Idaho Falls and the INEI, Site. The soils of interest for the calculations reported here were taken from Pit 9 of the SDA. There are $24,531 \mathrm{t}$ of soil in Pit 9. This has a nominal stoichiometry and (amount) of $\mathrm{K}_{2} \mathrm{O} 2.52 \%$ (618.2 $\mathrm{t}$ ), $\mathrm{Na}_{2} \mathrm{O} 1.3 .3 \%$ (326.3 t), $\mathrm{Al}_{2} \mathrm{O}_{3} 11.40 \%$ (2,796.5 t), $\mathrm{CaO} \& \mathrm{MgO} 9.97 \%$ $(2,445.7 \mathrm{t}), \mathrm{Fe}_{2} \mathrm{O}_{3} 4.07 \%$ (998.4 l), $\mathrm{SiO}_{2} 69.64 \%$ (17,083.4 l), and undefined other $1.07 \%$ $(262.5 \mathrm{t})$. The $618.2 \mathrm{t}(6.56 \mathrm{tmol})$ of potassium oxide is equivalent to $406.9 \mathrm{t}(6.56 \mathrm{t} \mathrm{mol})$ of sodium oxide. These amounts are used in the model.

There are $45.3 \mathrm{t}$ of Portland cement (not defined as concrete) in Pit 9. In addition to the cement used to formulate concrete, Portland cement was used to fill some drums of waste. The cement has a nominal stoichiometry and (amount) of $\mathrm{K}_{2} \mathrm{O} 0.51 \%(0.2 \mathrm{t}), \mathrm{Na}_{2} \mathrm{O} 0.21 \%(0.1 \mathrm{t})$, $\mathrm{Al}_{2} \mathrm{O}_{3} 5.6 \%$ (2.5 t), $\mathrm{CaO} 64.2 \%$ (29.1 l), $\mathrm{MgO} 3.7 \%$ (1.7 t), $\mathrm{Fe}_{2} \mathrm{O}_{3} 2.4 \%$ (1.1 t), $\mathrm{SiO}_{2} 20.7 \%$ $(9.4 \mathrm{t}), \mathrm{TiO}_{2} 0.23 \%(0.1 \mathrm{t}), \mathrm{SO}_{3} 1.6 \%(0.7 \mathrm{t})$, and undefined other $0.85 \%(0.4 \mathrm{t})$. The $0.2 \mathrm{t}$ $(0.0031 \mathrm{t} \mathrm{mol})$ of potassium oxide is equivalent to $0.19 \mathrm{t}(0.0031 \mathrm{tmol})$ of sodium oxide. The $1.7 \mathrm{t}(0.042 \mathrm{tmol})$ of magnesium oxide is equivalent $\mathrm{to} 2.36 \mathrm{t}(0.042 \mathrm{tmol})$ of calcium oxide. The sulfur trioxide and titania are insignilicant in the present analysis. The other amounts are used in the model.

The inorganic components, paper, rags, and wood in Pit 9 are summarized in Table 1. These data were used for modeling the equilibrium concentrations of materials in the ISV melt.

\section{Organic Materials in Pit 9}

The paper, rags, and wood in Pit 9, listed under Other Miscellaneous Chemicals, are modeled here as carbon, carbon dioxide, and water. There are a number of other organic materials in the wastes, primarily oils, solvents, and alcohol, which are modeled in this section. The overall composition of the organic materials in Pit 9 is given in Table 2. This includes the paper, rags, and wood. These data were used to estimate the equilibrium concentration of materials in the ISV melt.

Table 2. Components equivalent to organic chemicals in Pit 9 for modeling purposes.

\begin{tabular}{lr} 
Species & Tonnes \\
\hline $\mathrm{C}$ & 14.877 \\
$\mathrm{CH} 4$ & 19.129 \\
$\mathrm{CCl} 4$ & 30.984 \\
$\mathrm{H} 2 \mathrm{O}$ & 5.640
\end{tabular}


The $187.7 \mathrm{t}$ of paper, rags, and wood in Pit 9 are cellulose materials, and cellulose is a polymer of glucose. The polymer has a nominal composition of $\left|\mathrm{C}_{6} \mathrm{H}_{9}, \mathrm{O}_{6}\right|_{\mathrm{n}}$ and is about $40.7 \% \mathrm{C}$, $54.2 \% \mathrm{O}$, and $5.1 \% \mathrm{H}$. Cellulose decompeses at temperatures below those of the molten mass from the ISV process. According to the following stoichiometry:

$$
4 \mathrm{C}_{6} \mathrm{H}_{1} \mathrm{O}_{6}===>21 \mathrm{C}+3 \mathrm{CO}_{2}+18 \mathrm{H}_{2} \mathrm{O}
$$

the decomposition products are carbon dioxide gas, 35.0 t; water (steam), 85.9 t; solid carbon, $66.8 \mathrm{t}$. These values are used in the model.

There are several chlorinated hydrocarbon solvents in Pit 9. For this evaluation, these were modeled as carbon, methane, and carbon tetrachloricle. There are $13.92 \mathrm{~m}^{3}$ of carbon tetrachloride in the pit, yiclding $22.2 \mathrm{t}$ of carbon tetrachloride. There are $2.85 \mathrm{~m}^{3}$ of trichloroethylene in the pit, yielding an equivalent of 5.501 of carbon tetrachloride, 0.191 of methane, and $0.57 \mathrm{l}$ of carbon. There are $4.28 \mathrm{l}$ of trichlorocthanes in the pit, yielding an equivalent of $3.30 \mathrm{t}$ of carbon tetrachloride, $0.34 \mathrm{t}$ of methane (equivalent to $0.51 \mathrm{t}$ of carbon and $0.765 \mathrm{t}$ of water), and $0.17 \mathrm{t}$ of carbon.

The alcohols in Pit 9 were probably methanol, ethanol, and 2-propanol; for the model it was assumed to be ethanol, $\mathrm{C}_{2} \mathrm{H}_{6} \mathrm{O}$. The ethanol was assumed to decompose into carbon, methane, and water. There were $4.87 \mathrm{~m}^{3}$ of ethanol in the pit, yiclding $1.31 \mathrm{t} \mathrm{of} \mathrm{methane} \mathrm{(equivalent} \mathrm{to}$ $2.0 \mathrm{t}$ of carbon and $2.95 \mathrm{t}$ of water), $0.98 \mathrm{t}$ of carbon, and $0.98 \mathrm{t}$ of water.

There are gasoline and oil in Pit 9. These were modeled as saturated hydrocarbons having 12 carbon atoms in the chain. These have a nominal eomposition of $85 \%$ carbon and $15 \%$ hydrogen. They were assumed to decompese into carbon and methane during melting. There are $22.24 \mathrm{~m}^{3}$ of Texaco Regal oils, equivalent $\mathrm{to} 7.44 \mathrm{t}$ of carbon and $12.4 \mathrm{t}$ of methane. There are $9.00 \mathrm{~m}^{3}$ of used oil and $0.19 \mathrm{~m}^{3}$ of gasoline. These were modeled as $9.19 \mathrm{~m}^{3}$ of oil, yickding $2.87 \mathrm{t}$ of carbon and $4.31 \mathrm{lof}$ methane.

\section{Radionuclides in Pit 9}

There are a number of radionuclides in Pit 9. However, only uranium and plutonium have high enough concentrations to be of eoncern in the present analysis. The uranium amounts to $11.76 \mathrm{t}$, including unirradiated luel. The uranium is modeled as $\mathrm{UO}_{2}$. The plutonium amounts to $0.016 \mathrm{t}$ of $\mathrm{PuO}_{2}$. There are $3.59 \mathrm{l}$ of other radioactive wastes in Pit 9, but these are probably fission products and cannot be modeled without more data.

The radioisotopes in Pit 9 are summarized in Table 3. These data were used to estimate the equilibrium concentration of materials in the ISV melt.

For purposes of the present model, the "other" radionuclides are eonsidered to be fission products such as ${ }^{90} \mathrm{Sr}$ and ${ }^{137} \mathrm{Cs}$. These are considered to be strontium eompounds, which are chemically similar to calcium eompounds. The $3.59 \mathrm{l}$ of "other" radioisotopes is equivalent to $0.040 \mathrm{t}$ mol of strontium oxide or equivalent to $0 .(040) 1 \mathrm{~mol}$ of calcium oxide or $2.233 \mathrm{t}$ of $\mathrm{CaO}$. 
Table 3. Radioisotopes in Pit 9 for modeling purposes.

\begin{tabular}{lc} 
Species & Tonnes \\
\hline $\mathrm{PuO}_{2}$ & 0.016 \\
$\mathrm{UO}_{2}$ & 11.76 \\
Other & 3.59
\end{tabular}

One aspect of the composition not addressed above is the relative accuracy of the data. For the uranium and plutonium oxides, the data are probably aceurate to approximately $1 \%$. However, such accuracy should not be assumed throughout the entire Pit 9 data base. For example, the soil $(24,531 \mathrm{t})$ is probably not known to the nearest $1 \%$, or $245 \mathrm{t}$; in fact, there is $1.07 \%$ of "undefined other" in the soil for $262.5 \mathrm{l}$. Thus, the total of all of the assumptions regarding composition of the Pit 9 materials, e.g., hydrous oxides, are far less than the "undefined other" in the soil. In the radioisotopes, there are $3.5 \% 1$ of "unidentilied" radioisotopes, probably fission products such as cobalt. Modeling these as iron oxide, $\mathrm{Fe}_{2} \mathrm{O}_{3}$, is probably a reasonable modeling assumption. Further, the round-off error from three figures behind the decimal point to one or two is also within the probable error of the overall material balance in the pit.

The species and quantities noled in Table 4 were used as input for the STEPSOL computer code to estimate the equilibrium eomposition of the melt and its gas phase. 
Table 4. Input data for STEPSOL model of Pit 9.

\begin{tabular}{llr}
\hline \multicolumn{1}{c}{ Species } & Formula & Tonnes \\
\hline Carbon & $\mathrm{C}$ & \\
Oxygen & $\mathrm{O}_{2}$ & 89.84 \\
Water & $\mathrm{H}_{2} \mathrm{O}$ & 178.71 \\
Carbon dioxide & $\mathrm{CO}_{2}$ & 49.42 \\
Carbon te:rachloride & $\mathrm{CCl}_{4}$ & 18.4 \\
Iron oxide, hematite & $\mathrm{Fc}_{2} \mathrm{O}_{3}$ & 15.84 \\
Iron & $\mathrm{Fc}_{3}$ & $1,168.9$ \\
Nickel + chromium and maganese + chromium oxide & $\mathrm{Ni}$ & 543.8 \\
Calcium oxide + magnesium oxide + heryllia + baritc & $\mathrm{CaO}$ & 90.26 \\
+ zirconia + fission products & & $2,618.41$ \\
Sodium oxide + potassium oxide + lithium oxide + & $\mathrm{Na}_{2} \mathrm{O}$ & \\
sodium and potassium nitrates & & 909.84 \\
Aluminum oxide & $\mathrm{Al}_{2} \mathrm{O}_{3}$ & \\
Silicon dioxide & $\mathrm{SiO}_{2}$ & $2,806.9$ \\
Uranium oxide & $\mathrm{UO}_{2}$ & $17,173.8$ \\
Plutonium oxide & $\mathrm{PuO}_{2}$ & 11.76 \\
\hline & & 0.016 \\
\hline
\end{tabular}




\section{MODEL}

The model developed should be applicable to in situ and ex situ vitrification, to incincration, and to a melter. The melter in question would be at the outlet of an incinerator and would melt the solids and thereby reduec the volume.

\section{Temperature}

Temperatures ranged from $8(0)$ to $2,400 \mathrm{~K}\left(527^{\circ} \mathrm{C} / 980.6^{\circ} \mathrm{F}\right.$ lo $\left.2,127^{\circ} \mathrm{C} / 3,861.6^{\circ} \mathrm{F}\right)$. This covers the range of interest for hazardous waste incineration. The calculations were made in $100 \mathrm{~K}$ increments. These are equilibrium calculations, and there is no differentiation between the solid and gas phases.

\section{Pressure}

Pressure input to STEPSOL is in atmospheres rather than the SI unit of pascals. The pressure was set at one atmosphere, $1.013 \times 10^{5}$ pascals.

\section{Composition of Input Waste}

Table 4 provides the input eomposition for the model. STEPSOL is limited to 14 constituents in the input. The model assumes that no fuel or air is admitted to the system, i.e., the melting is done by joule heating or is heated by an external energy souree that does not add to the melt composition.

There are insullicient options in the input of STEPSOL. to include the toxic and high vapor pressure metals (HVPMs). However, all of the HVPMs except barium should be reducible by the carbon or aluminum in Pit \%. On this basis, a scparate analysis of the HVPMs was made. In this separate analysis, the vapor pressures of the metals were estimated as a lunction of temperature. The algorithm used is the logarithm of the reported vapor pressure plotted versus the reciprocal of the absolute temperature, yielding straight lines, shown in Figure 14 and Figure 15. Some metals, such as mercury, would be completely vaporized at low temperatures. In other cases, the partial pressure of each of the metals was estimated, and a summation of the partial pressure of the HVPMs was made. This was then compared with the gas phase composition at a pressure of one atmosphere. An estimate of the compositions of the HVPMs and the gas phase was then made at a total pressure of one atmosphere.

\section{Composition of Output Streams}

Table 5 is a list of the eonstituents in the output gas stream. The model assumes that all gases remain in the system and are in thermodynamic equilibrium with the slag and metal phases. For purposes of the model, it was assumed that any plutonium or uranium oxyhydroxides would be in the gas phase. This may be an unwarranted assumption. The HVPMs are listed in this table. 


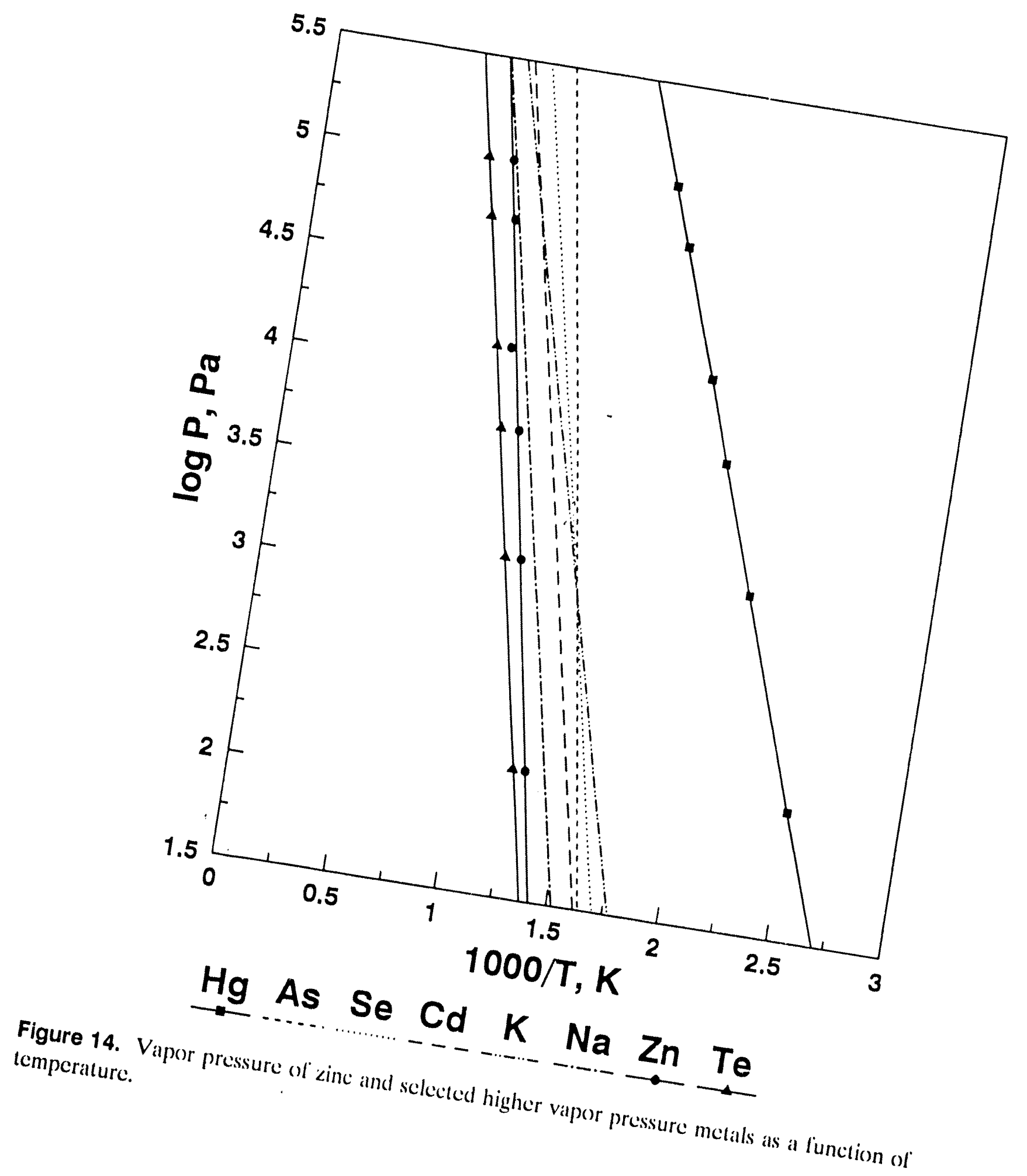




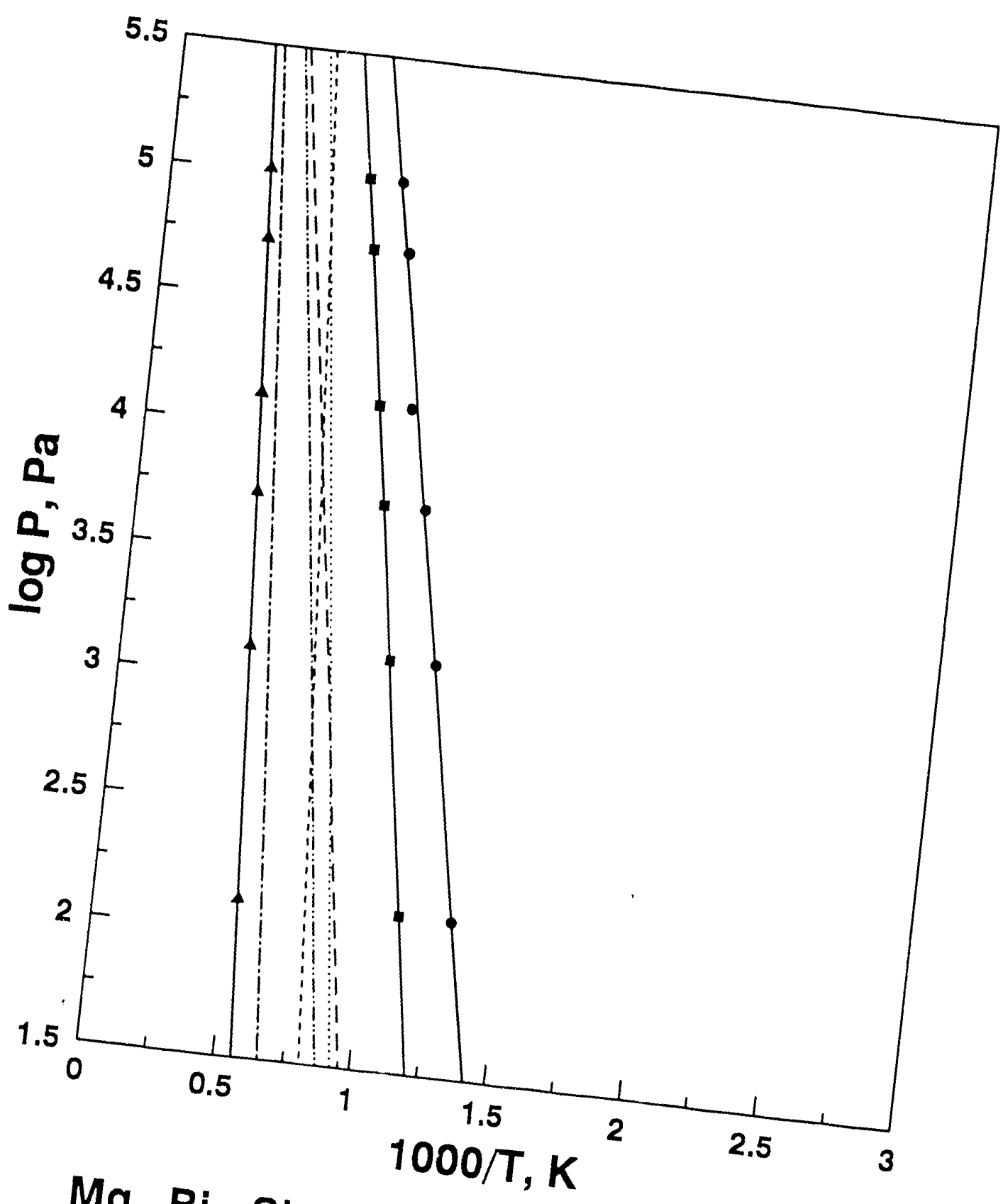

Figure 15. Vipor pressur.... $\mathrm{Sb} \quad \mathrm{Pb} \quad \mathrm{Ag} . \mathrm{Zn} \quad \mathrm{Cr}$ temperature. 
Table 5. Constituents of the output gas phase.

Species

Formula

Elements

Hydrogen $\quad \mathrm{H}_{2}$

Chlorine $\quad \mathrm{Cl}_{2}$

Oxygen $\quad \mathrm{O}_{2}$

Oxides

Water

Carbon monoxide

$\mathrm{H}_{2} \mathrm{O}$

Carbon dioxide $\quad \mathrm{CO}_{2}$

Chlorides

Aluminum chloride

Carbon tetrachloride

$\mathrm{AlCl}_{3}(\mathrm{~g})$

Hydrogen chloride

$\mathrm{CCl}_{4}$

Iron (II) chloride

$\mathrm{HCl}$

Iron (III) chloride

$\mathrm{FeCl}_{2}(\mathrm{~g})$

$\mathrm{FeCl}_{3}(\mathrm{~g})$

Other

Methane

$\mathrm{CH}_{4}$

Plutonium oxyhydroxide

$\mathrm{PuO}_{2}(\mathrm{OH})_{2}$

Uranium oxyhydroxide

$\mathrm{UO}_{2}(\mathrm{OH})_{2}$

Toxic and high vapor pressure metals

$\begin{array}{ll}\text { Antimony } & \mathrm{Sb} \\ \text { Arsenic } & \mathrm{As} \\ \text { Barium } & \mathrm{Ba} \\ \text { Bismuth } & \mathrm{Bi} \\ \text { Cadmium } & \mathrm{Cd} \\ \text { Chromium } & \mathrm{Cr} \\ \text { Potassium } & \mathrm{K} \\ \text { Lead } & \mathrm{Pb} \\ \text { Magnesium } & \mathrm{Mg} \\ \text { Mercury } & \mathrm{Hg} \\ \text { Sclenium } & \mathrm{Se} \\ \text { Tellerium } & \mathrm{Te} \\ \text { Silver } & \mathrm{Ag} \\ \text { Sodium } & \mathrm{Na} \\ \text { Zinc } & \mathrm{Zn}\end{array}$


Table 6 lists the constituents of the slag phase. Some of the constituents melt before the highest temperature of the system model is reached. Upon melting, these constituents lose their identity. In some cases, the available thermodynamic data are limited. Further, the liquid phase may provide a solve:.t for dissolving other constituents of the slag or metal phases. No account is taken of these melting phases. Plutonium and uranium compounds are listed in Table 7.

Table 8 lists the constituents of the metal phase and their melting temperatures. All of these metals melt before the highest temperature of the system model is reached. Molten metals may be solvents for some of the slag or gas phase constituents. However, when freezing occurs, the gases would be exsolved; and most of the slag constituents would be in the slag phase. In this respect, the metal and slag phases act in the same manner as a solvent extraction system. Table 5 also lists the HVPMs considered in the present analysis.

Table 6. Slag phase species that would be generated from the materials in Pit 9. Plutonium and uranium compounds are not included even though they may be in the slag phase.

\section{Species}

Chlorides

Aluminum chloride

Calcium chloride

Iron (II) chloride

Iron (III) chloride

Sodium chloride

Oxicles

Alumina

Silica

Wuestite

Magnetite

Hematite

Nickel oxide

Silicates

Calcium olivine

Anorthite

Grossular

Wustite

Sodium silicate

High albite

Jadeite
Formula

$\mathrm{AlCl}_{3}$

$\mathrm{CaCl}_{2}$

$\mathrm{FeCl}_{2}$

$\mathrm{FeCl}_{3}$

$\mathrm{NaCl}$
$\mathrm{Al}_{2} \mathrm{O}_{3}$
$\mathrm{SiO}_{2}$
$\mathrm{FeO}$
$\mathrm{Fe}_{3} \mathrm{O}_{4}$
$\mathrm{Fe}_{2} \mathrm{O}_{3}$
$\mathrm{NiO}$

$\mathrm{Ca}_{2} \mathrm{SiO}_{4}$
$\mathrm{CaAl}_{2} \mathrm{Si}_{2} \mathrm{O}_{8}$
$\mathrm{Ca}_{3} \mathrm{Al}_{2} \mathrm{Si}_{2} \mathrm{O}_{12}$
$\mathrm{Fe}_{2} \mathrm{SiO}_{4}$
$\mathrm{Na}_{2} \mathrm{SiO}_{5}$
$\mathrm{NaAlSi}_{3} \mathrm{O}_{8}$
$\mathrm{NaAlSi}_{2} \mathrm{O}_{6}$


Table 7. Uranium and plutonium species that would be generated from the materials in Pit 9. Some species will be in the gas phase, some in the slag phase, and others in the metal phase.

Species

Formula

Plutonium

Plutonium dioxide

Plutonium monoxide

Plutonium oxyhydroxide

Plutonium trichloride

Uranium

Uranium dioxide

Uranium trioxide

Uranium trichloride

Uranium tetrachloride

Uranium oxyhydroxide

Sodium uranate

Sodium uranium oxide
$\mathrm{Pu}$

$\mathrm{PuO}_{2}$

$\mathrm{PuO}$

$\mathrm{PuO}_{2}(\mathrm{OH})_{2}$

$\mathrm{PuCl}_{3}$

$\mathrm{U}$

$\mathrm{UO}_{2}$

$\mathrm{UO}_{3}$

$\mathrm{UCl}_{3}$

$\mathrm{UCl}_{4}$

$\mathrm{UO}_{2}(\mathrm{OH})_{2}$

$\mathrm{Na}_{2} \mathrm{UO}_{4}$

$\mathrm{Na}_{3} \mathrm{UO}_{4}$

Table 8. Metallic phase species that would be generated from the materials in Pit 9.

\begin{tabular}{llc}
\multicolumn{1}{c}{ Species } & $\begin{array}{c}\text { Melting } \\
\text { point }\end{array}$ & Kelvin \\
\hline Aluminum & $\mathrm{Al}$ & 933 \\
Carbon & $\mathrm{C}$ & 4,100 \\
Iron & $\mathrm{Fe}$ & 1,809 \\
Nickel & $\mathrm{Ni}$ & 1,726 \\
Plutonium & $\mathrm{Pu}$ & 910 \\
Silicon & $\mathrm{Si}$ & 1,685 \\
Uranium & $\mathrm{U}$ & 1,405 \\
& & \\
\hline
\end{tabular}




\section{RESULTS AND DISCUSSION}

As noted earlier, thermodynamic relationships between the elements and their compounds may be presented graphically. These graphs are termed Ellingham diagrams and are curves of Gibbs energy of formation as a function of absolute temperature. When mixtures of reacting elements and compounds are encountered, it becomes necessary to estimate the thermodynamic relationships between the various components. For example, in the carbon-hydrogen-oxygen system, it is necessary to consider methane, in addition to the elements and their oxides.

The difference between two curves on an Ellingham diagram is a measure of the thermodynamic tendency towards reaction. Simply finding the dilference in the Gibbs energy between two compounds is only part of the solution to the equilibrium thermodynamics problem, e.g., it does not estimate the relative abundance of the reactants and products in an equilibrium mixture after reaction. This is estimated by Gibbs energy minimization calculations. The major problem of the present study is to make these calculations using the materials in Pit 9.

STEPSOL was used in estimating the relative stability of the Pit 9 materials to find the minimum Gibbs energy that satisfied the stoichiometry of the system. However, this program is limited to 14 species that can be specilied for the input of a problem. For this reason, a number of simplifying assumptions were made concerning the composition of the materials in Pit 9. Table 4 lists the species and the amounts used in the present analysis.

Table 9 provides the amounts of gas, slag, and metal phases from the Pit 9 materials as a function of temperature. The data show that the mass of the gas phase increases by a factor of more than 10 between 800 and $2,400 \mathrm{~K}$. This would be expected because the stability of slag phase compounds decreases while the stability of carbon monoxide increases with temperature. The Gibbs energy of lormation lor carbon dioxide shows little change with temperature.

Table 10 gives the amounts of uranium and plutonium and their oxyhydroxides and chlorides that would be generated from the materials in Pit 9. Of particular concern are the uranium and plutonium oxyhydroxides, because these were thought to have very high vapor pressures at high temperatures and pressures. Under the conditions of incineration, melting, or ISV of Pit 9, the pressure would be about one atmosphere. The amount of plutonium oxyhydroxide that would be in equilibrium with the slag would be $3.4 \mu \mathrm{g}$ at $2,000 \mathrm{~K}$. The uranium oxyhydroxide could be as much as $19 \mathrm{mg}$ at $2,000 \mathrm{~K}$ and $50 \mathrm{~g}$ at $2,400 \mathrm{~K}$. Metal chlorides tend to have high vapor pressures, which increase with temperature. The largest amount of plutonium chloride, $\mathrm{PCl}_{3}$, that would be formed is less than $1.3 \mathrm{mg}$ at $2,000 \mathrm{~K}$. The largest combined amounts of uranium trichloride and uranium tetrachloride that would be formed are less than $1 \mu \mathrm{g}$ at 2,000 $\mathrm{K}$, respectively. These compounds may have high vapor pressures and could, therefore, be found in the gas phase. However, vapor pressure data as a function of temperature are not available for making predictions of the amount of each of the compounds that might be found in the vapor phase. Further, the thermodynamic activity of the compounds in the slag phase is unknown. These data are required for estimation of the pressure of the compounds in the vapor phase that would be in equilibrium with the same compounds in the slag phase using Henry's law. A risk analysis with respect to allowable plutonium and uranium releases is beyond the scope of the present task. 


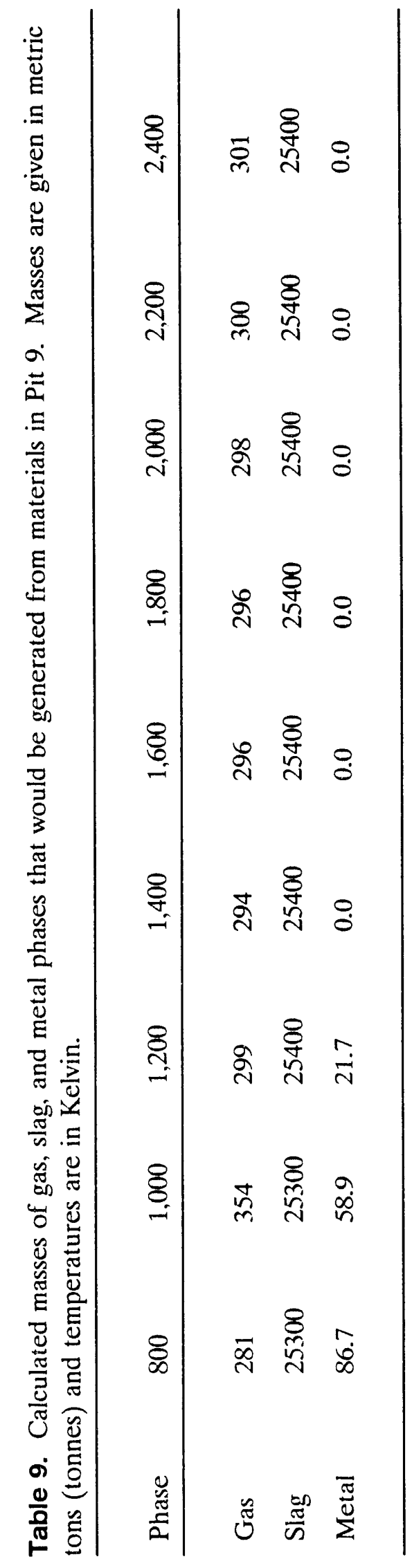




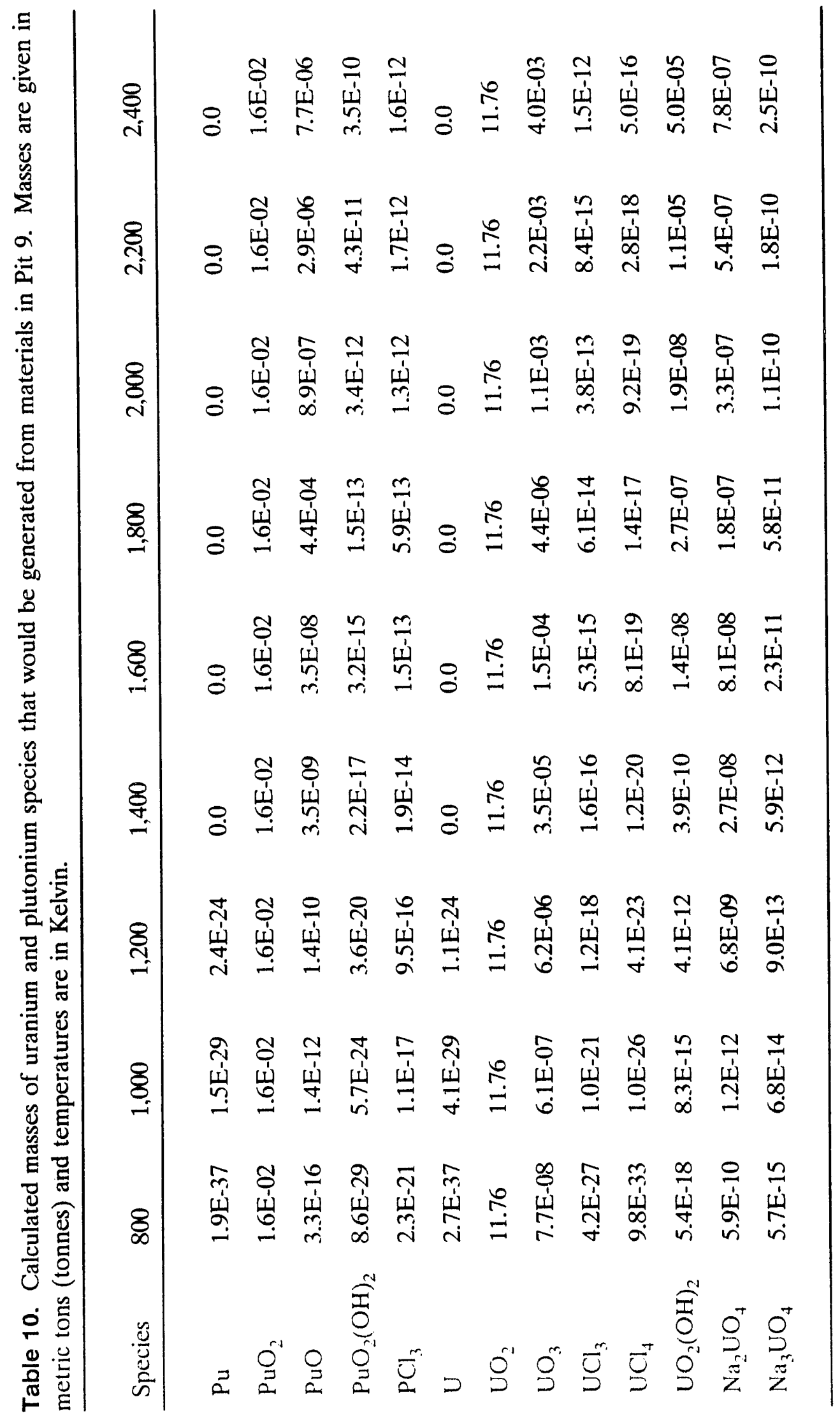


Table 11 shows the calculated masses of gas phase species that would be generated from the materials in Pit 9. Plutonium and uranium compounds are not included. The system is very reducing as seen by the amounts of hydrogen and oxygen in the gas phase. The methane concentration decreases with increasing temperature while the carbon monoxide concentration increases with temperature. These trends are a reflection of their Gibbs energy of formation as a function of temperature.

As noted previously, the chlorinated hydrocarbons in Pit 9 were modeled as carbon tetrachloride. The calculated amount of carbon tetrachloride would be less than $1 \mu \mathrm{g}$ at any temperature. The carbon tetrachloride decomposes to form hydrogen chloride. Hydrogen chloride is the second most abundant material in the gas phase at temperatures reaching $2,400 \mathrm{~K}$. This indicates that chlorinated hydrocarbons should not be a problem if they can be retained in the hot zone long enough to react with other materials. (Upon cooling, a portion of the hydrogen chloride would combine with the water to form highly corrosive hydrochloric acid.)

Table 12 gives the calculated masses of metallic phase species that would be generated from the materials in Pit 9. Nickel, chromium, manganese, and molybdenum are combined as nickel. Iron is the most abundant component of the metals in the system and amounts to 600 to $1,200 \mathrm{t}$. Nickel is the next most abundant metal, being about $90 \mathrm{t}$. Carbon was included with the metals because of its tendency to form alloys with transition metals. The amount of carbon varies from approximately $0.11 \mathrm{t}$ at $2,400 \mathrm{~K}$ to $94.7 \mathrm{l}$ at $1,000 \mathrm{~K}$. This exceeds that which could be dissolved into the metals, and a separate carbon phase would be expected to form upon cooling. Note that the amounts of metallic plutonium and uranium are small.

Table 13 gives the calculated masses of chloride, oxide, and silicate species in the slag phase that would be generated from the materials in Pit 9. Plutonium and uranium compounds are not included. Sodium chloride is the most abundant of the chlorides, and its mass decreases from $24.1 \mathrm{t}$ at $800 \mathrm{~K}$ to $7.7 \mathrm{t}$ at $2,400 \mathrm{~K}$. The mass of iron(II) chloride is seen to increase from less than $1 \mathrm{~g}$ at $800 \mathrm{~K}$ to $2 \mathrm{~kg}$ at $2,400 \mathrm{~K}$. The amount of calcium chloride increases from $32 \mathrm{~g}$ to $40 \mathrm{~kg}$ between $800 \mathrm{~K}$ and $1,000 \mathrm{k}$ then decreases to $7.7 \mathrm{t}$ at $2,400 \mathrm{~K}$. Iron(III) chloride and aluminum chloride are present in trace amounts. Calcium, iron(II), and sodium chloride have high vapor pressures and would be expected to be present in the gas phase. However, their thermodynamic solution activities in the slag are unknown, and their vapor pressures cannot be estimated without these data. Aluminum chloride forms a dimer, $\mathrm{Al}_{2} \mathrm{Cl}_{6}$, in the vapor phase. However, the amount of aluminum chloride formed from Pit 9 materials is less than a gram at any temperature. Similarly, iron(III) chloride forms a dimer, $\mathrm{Fe}_{2} \mathrm{Cl}_{6}$, in the gas phase. However, only about $0.8 \mathrm{~g}$ would be formed from Pit 9 materials.

Of the oxides, silica $\left(\mathrm{SiO}_{4}\right)$, wuestite $(\mathrm{FeO})$, and alumina $\left(\mathrm{Al}_{2} \mathrm{O}_{3}\right)$ are the most abundant in the slag. Silica accounts lor approximately $13,0(0) \mathrm{t}$ of the slag phase; alumina is about $2.5 \mathrm{t}$. Wuestite, FeO, is present in moderate amounts, but accounts for less than $1 \mathrm{t}$; the other iron oxides, magnetite, $\mathrm{Fe}_{3} \mathrm{O}_{4}$, and hematite, $\mathrm{Fe}_{2} \mathrm{O}_{3}$, have very low coneentrations in the slag. This reflects the reducing nature of the system.

Calcium olivine, $\mathrm{Ca}_{2} \mathrm{SiO}_{4}$, layalite, $\mathrm{Fe}_{2} \mathrm{SiO}_{4}$, and sodium silicate, $\mathrm{Na}_{2} \mathrm{Si}_{2} \mathrm{O}_{5}$, are the most abundant of the simple silicates, amounting to about $3,200 \mathrm{t}$ of the slag at $2,400 \mathrm{~K}$. The amounts 


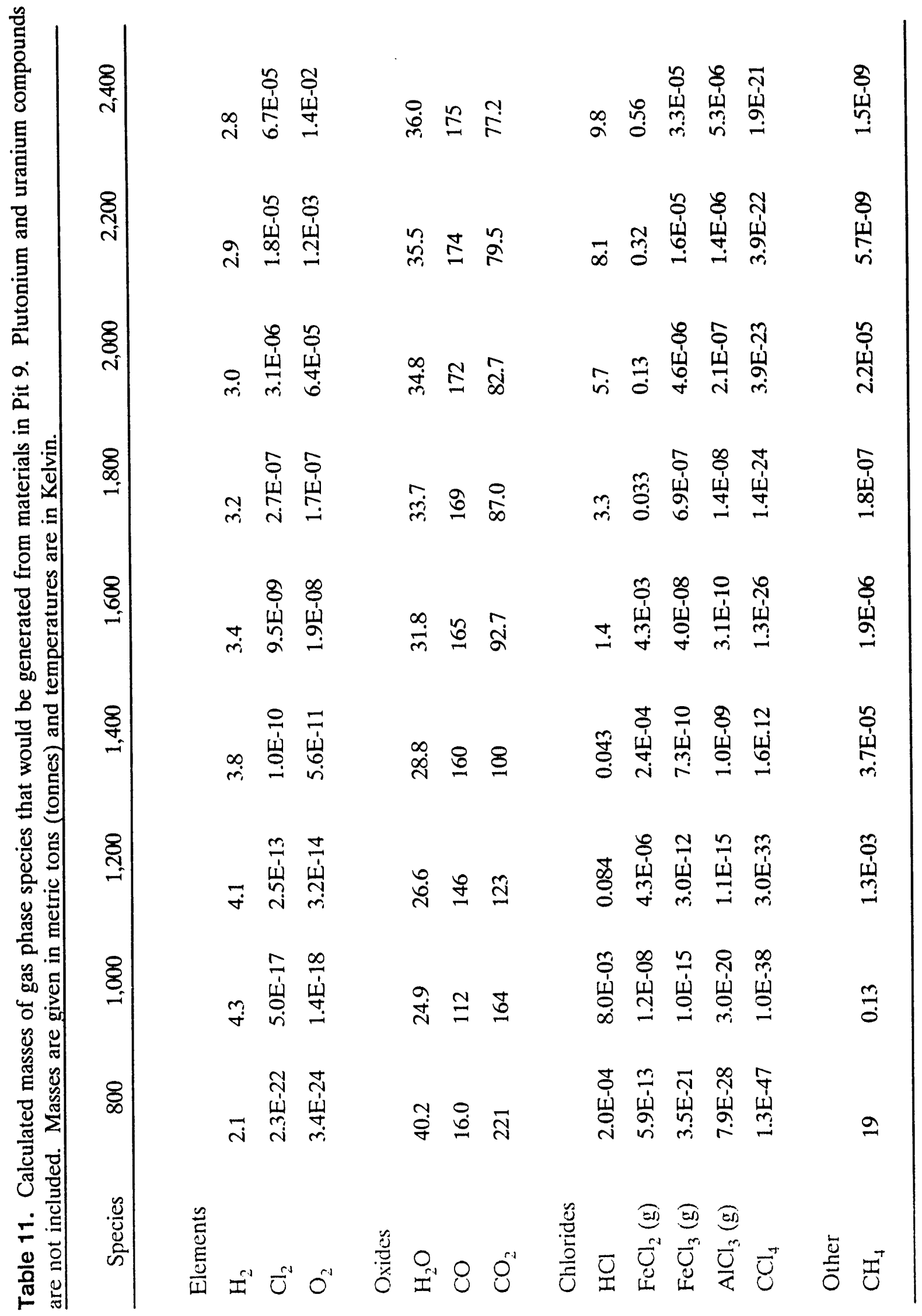




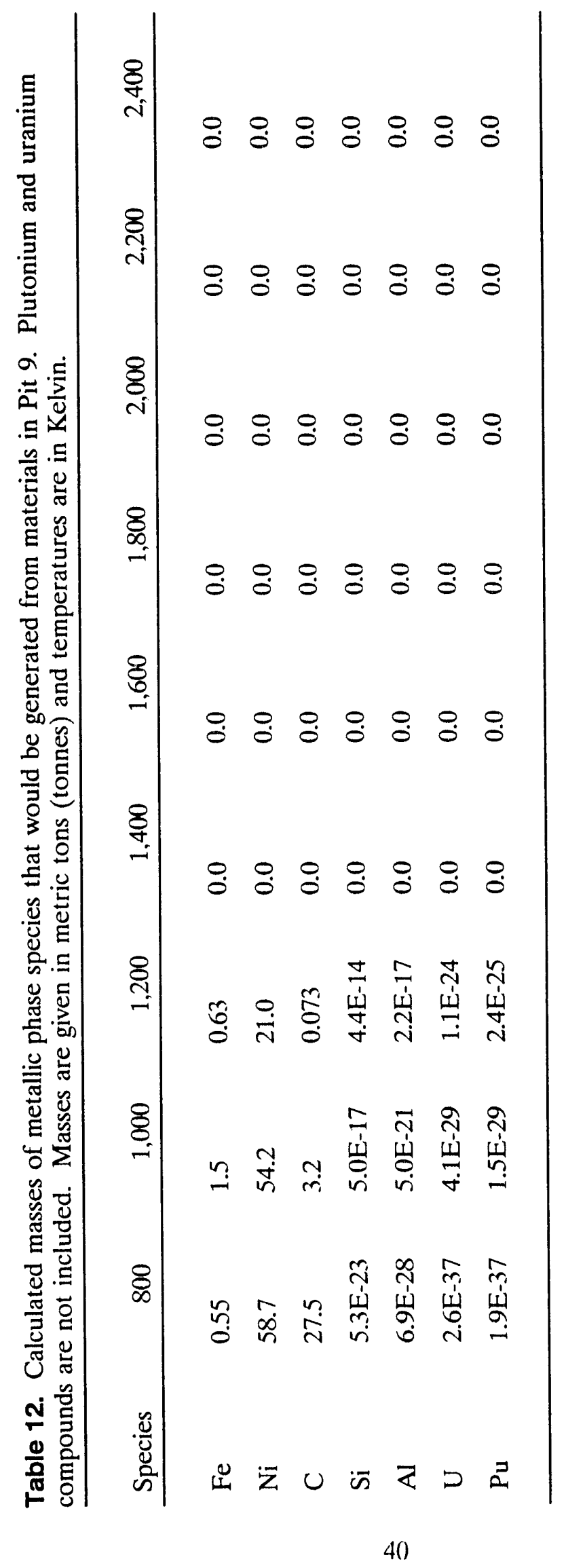




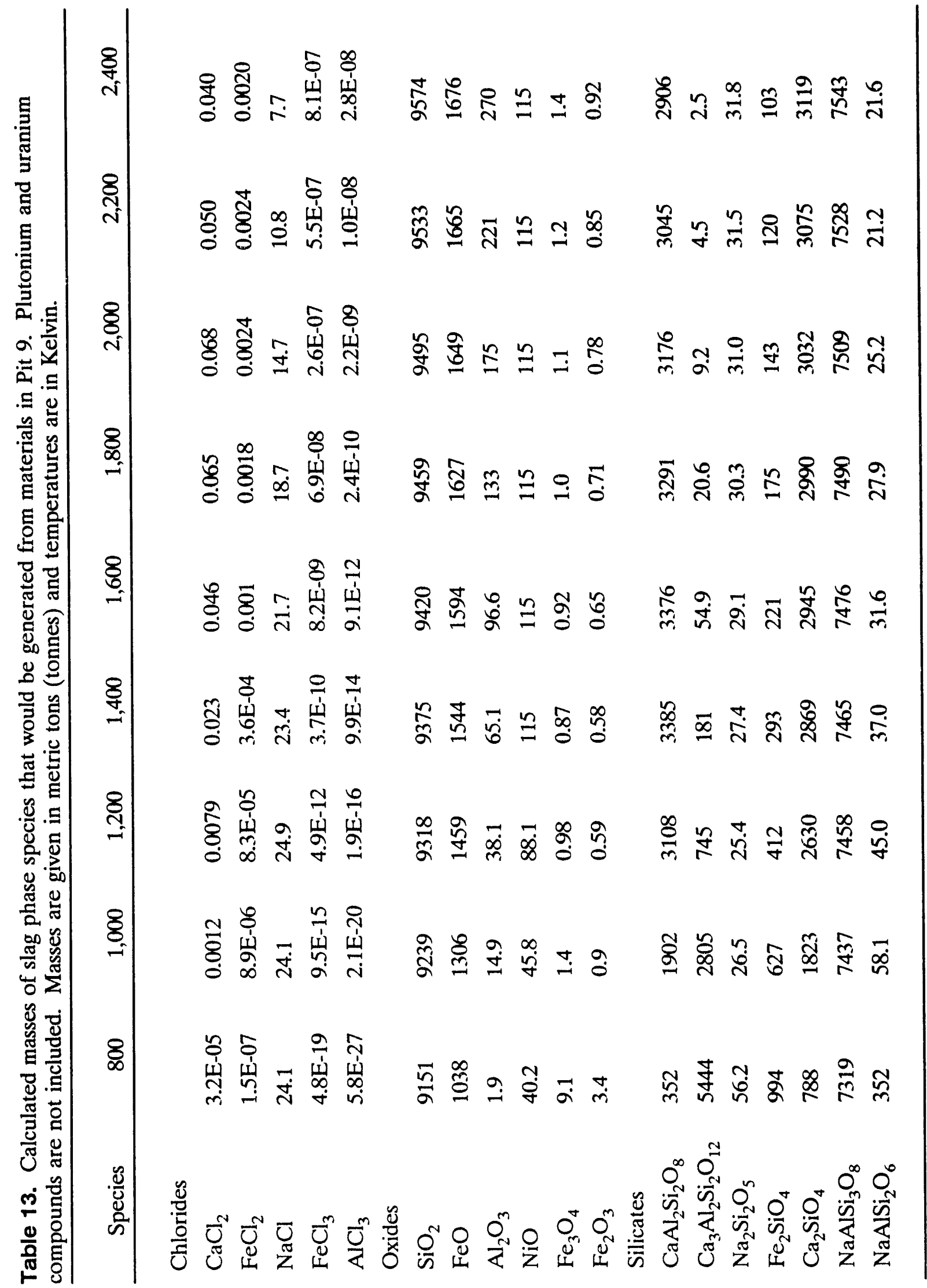


increase with increasing temperature. Anorthite, $\mathrm{CaAl}_{2} \mathrm{Si}_{2} \mathrm{O}_{8}$, is the most abundant of the silicates and accounts for $3,385 \mathrm{t}$ at $1,400 \mathrm{~K}$. The amounts of anorthite decrease at lower and at higher temperatures. Grossular, $\mathrm{Ca}_{3} \mathrm{Al}_{2} \mathrm{Si}_{3} \mathrm{O}_{12}$, is the next most abundant of the silicates and accounts for $5,444 \mathrm{t}$ at $800 \mathrm{~K}$. The amount of grossular decreases with increasing temperature. Other complex silicates, such as jadeite, $\mathrm{NaAl}\left(\mathrm{SiO}_{3}\right)_{2}$, and albitc, $\mathrm{NaAlSi}{ }_{3} \mathrm{O}_{8}$, have very low concentrations at low temperatures, but could be as much as $3.4 \mathrm{l}$ at $2.400 \mathrm{~K}$. 


\section{CONCLUSIONS}

STEPSOL is limited to 14 input species, which limits the accuracy of the resulting estimates of phase composition.

There are about $16 \mathrm{~kg}$ of plutonium oxide in Pit 9. The amount of this plutonium present in the gas phase may be represented by the mass of plutonium oxyhydroxide, $\mathrm{PuO}_{2}(\mathrm{OH})_{2}$. This varies from less than $10^{-28} \mathrm{~g}$ at $800 \mathrm{~K}$ to less than $10^{-9} \mathrm{~g}$ at $2,400 \mathrm{~K}$. There are $11.76 \mathrm{t}$ of uranium oxide in Pit 9. The amount of this uranium that could be in the gas phase may be represented by the calculated mass of uranium oxyhydroxide, $\mathrm{UO}_{2}(\mathrm{OH})_{2}$. This varies from less than $10^{-17} \mathrm{~g}$ at $800 \mathrm{~K}$ to $50 \mathrm{~g}$ at $2,400 \mathrm{~K}$. A risk analysis for these compounds was beyond the seope of this task and was not made.

The calculations show that the system is reducing but becomes less so with increasing temperature. Reference to Figure 3 shows that the iron-oxygen system is complex with respect to stable species. Above approximately $1,900 \mathrm{~K}$, only liquids are present. These liquids are solutions of iron and/or iron oxides. In some ciases, the liquids are not miscible; and more than one liquid phase may be present. The impact of this on the metals and slags is that partitioning of species between the separate liquid phases will oecur. The partition coeflicient provides some measure of the thermodynamies. Plutonium, for example, lavors the slag phase of iron or stainless stecl over the metallic phase by a lactor of approximately $10^{6}$. From this, it may be concluded that any plutonium produed would tend to be rejected from the metallic phase into the slag phase. The amounts of metallic plutonium that would be produced from the $16 \mathrm{~kg}$ of plutonium oxide in Pit 9 varies from less than $10^{-31} \mathrm{t}$ at $700 \mathrm{~K}$ to less than $10^{-10} \mathrm{t}$ at $2,000 \mathrm{~K}$. There are $11.76 \mathrm{t}$ of uranium oxide in Pit 9. At $700 \mathrm{~K}$, less than $10^{-30} 1$ will be in the metallic phase; and at $2,000 \mathrm{~K}$, less than $10^{-9} \mathrm{t}$ would be in the metallic phase. Exeept for similar amounts of uranium and plutonium compounds in the gas phase, the remainder would be in the slag phase.

The slag phase is largely silica and silicates, accounting lor approximately $21,0(0) \mathrm{t}$ of the materials in Pit 9. Lesser amounts of iron oxides are produced, and wuestite, FeO, is the most predominante iron oxide. Magnetite, $\mathrm{Fe}_{3} \mathrm{O}_{4}$, and hematite, $\mathrm{Fe}_{2} \mathrm{O}_{3}$, are present in small amounts. The very small coneentrations of higher oxidation-state iron oxides indicale that the slag is reducing. Simple silicates of sodium, calcium, and iron account for approximately 1,800 t of the slag. Complex silicates such as jadeite and albite represent 7,400$)$ to 7,600$) \mathrm{t}$.

One feature of the reducing state of the slag and resulting high concentrations of wuestite, $\mathrm{FeO}$, is the higher leachability of this oxide compared with other iron oxides. This, coupled with the sodium chloride and sodium silicate in the slag could make these slags more susceptible to leaching, compared, for example, to iron-enriched basalt.

Metal chlorides account for small amounts of the slag. Calcium, sodium, and iron(I1) and iron(III) chlorides have relatively high vapor pressures. These compounds could be present in the gas phase or the slag phase, depending on temperature and thermodynamic activity.

Thermodynamic solution-activity data are not available for most of the products that could contribute to the pressure of the gases in the system. For this reason, accurate concentration calculations cannot be made.

The high vapor pressure metals could not he analyzed using STEPSOL. However, as a first approximation, all of the mercury should be in the gas phase. Similarly, any arsenic, selenium, or tellurium should be vaporized during incineration or melting. 


\section{REFERENCES}

1. W. Vogel, Chemistıy of Glass, Am. Ccramic Soc., Columbus, OH, 1985.

2. L. S. Darken and R. W. Gurry, Physical Chemistiy of Metals, McGraw-Hill, New York, 1953.

3. Y. K. Roa and B. P. Jalan, "A Study of the Rates of Carbon-Carbon Dioxide Reaction in the Temperature Range $8.39^{\circ}$ to 1,050 $0^{\circ}$," Met. Trans., 3, 1972, pp. 2,465-2,477.

4. L. B. Pankratz, Thermodynamic Properties of Halides, U.S. Bureau of Mines, Bul. 674, 1984.

5. M. H. Rand, "Plutonium: Physico-Chemical Properties of Its Compounds and Alloys, I. Thermochemical Properties," Alomic Energy Review, Special Issue No. 1, 1966.

6. R. J. MacKinnon, D. C. Mecham, D. L. Hagrman, R. W. Johnson, P. E. Murry, C. E. Slater, E. S. Marwil, R. Weaver, and M. Argyle, Modeling Requirements for In Situ Vitrification, EGG-WM-9(035, July 1990).

7. J. L. Plum, SECHT-IV Performance Evaluation of Stainless Stecl-and Zircaloy-Clad Electrically Powered Heaters, U.S. AEC Report, IN-1378, June 1970.

8. Letter from R. L. Miller to D. H. Walker, "Thermodynamics of the Reaction Between Alumina and Zirconium," RLM-3-7(), September 2, 197().

9. M. J. Graber, W. F. Zelezny, and R. E. Schmunk, A Metallurgical Evaluation of Simulated BWR Emergency Core Cooling Tests, U.S. AEC Report, IN-1453, March 1971.

10. T. B. Massalski (ed.), Binary Alloy Phase Diagrams, Amer. Soc. Metals, Metals Park, OH, 1986.

11. N. Levitz et al., "Volume Reduction and Salvage Considerations for Plutonium-Contaminated Ferrous Metals," AIChE Symposium Series, 72, 154, 1976, pp. 86-89.

12. M. G. Seitz, T. J. Gerding, and M. J. Steindler, Decontamination of Metals Containing Plutonium and Americium, ANL-78-13, June 1979.

13. G. L. Copeland, R. L. Heestand, and R. S. Matecr, Volume Reduction of Low-Level Contaminated Metal Waste by Melting-Selection of Method and Conceptual Plan, ORNL/TM-6388, June 1978.

14. B. Heshmatpour and G. L. Copcland, The Effects of Slag Composition and Process Variables on Decontamination of Metallic Wastes by Melt Refining, ORNL/TM-7501, January 1981.

15. B. Heshmatpour, G. L. Copeland, and R. L. Heestand, Decontamination of Tiansuranic Waste Metal by Melt Refining, ORNL/TM 7951, Oak Ridge, TN, 1981, 25 pp.

16. C. W. Hobbick, D. R. Schatz, and G. D. Aden, Distribution and Removal of Radionuclides in Molten Stainless Steel, RHO-CD-1444, 1981.

17. C. W. Bale and G. Ericksson, "Metallurgical Thermochemical Databases-A Review," Can. Met. Quart., 29, 2, 1990, pp. 105-132. 
18. T. M. Besmann, SOLGASMIX-PV, A Computer Program to Culculate Equitibrium Relationships in Complex Chemical Systems, ORNL/TM-5775, April 1977.

19. D. May and D. F. Rudd, "Accessible Design in Solvay Cluster Synthesis," Chem. Eng. Sci., 31, 1976, pp. 701-703.

20. J. M. Beller, G. S. Carpenter, W. C. Schutte, D. F. Suciu, and K. A. Prisbrey, Thermodynamic Assessment Tools for Potential Solvay-Type Heat of Reaction Chemical Heat Pumps, EGG-CS-7.370, January 1987.

21. M. W. Chase, Jr., C. A. Davies, J. R. Downcy, Jr., J. J. Frurip, R. A. McDonald, and A. N. Syverud, JANAF Thermochemical Tables, 3rd edition, Amer. Chem. Soc., Washington, D.C. 1986. Also listed as J. Phys. Chem. Ref. Data, 14, Supplement No. 1, 1985.

22. I. Barin and O. Knacke, Thermochemical Properties of Inorganic Substances, Springer-Verlan, Berlin, 1973.

23. O. Kubaschewski, E. L. Evans, and C. B. Alcock, Metallurgical Thermochemistry, Pergamon Press, 1967.

24. L. B. Pankratz, Thermodynamic Properties of Elements and Oxides, U.S. Bureau of Mines, Bul. 672, 1982.

25. R. A. Robic, B. S. Hemingway, and J. R. Fisher, Thermodynamic Properties of Minerals and Related Substances at $298.15 \mathrm{~K}$ and 1 Bar Pressure and at Higher Temperatures, U.S. Geological Survey, Bul. 1,452, 1978.

26. Texas A\&M University, Texas A\&M Data Base, Thermodynamic Research Center Hydrocarbon Project and Data Project, Vols. I-X, 1984.

27. Standard for Metric Practice, Standard E 380-79, Am. Soc. Test. Mat., Philadelphia, PA, 1980.

28. I. M. Koltholf, E. B. Sandell, E. J. Mechan, and S. Bruckenstcin, Quantitative Chemical Analysis, 4th edition, Macmillan Co., London, 1969, p. 588.

29. G. C. Lewis, M. A. Fosberg, R. E. McDole, and J. C. Chugg, "Distribution and Some Properties of Loess in Southecntral and Southeastern Idaho," Soil Sci. Amer: Proc., 39, 6, November-December 1975, pp. 1,165-1,168.

30. J. B. Robertson, R. Schoen, and J. T. Barraclough, The Influence of Liquid Waste Disposal on the Geochemistly of Water at the National Reactor Testing Station, Idaho: 1952-70, USGS Open-File Report, IDO 22053. 

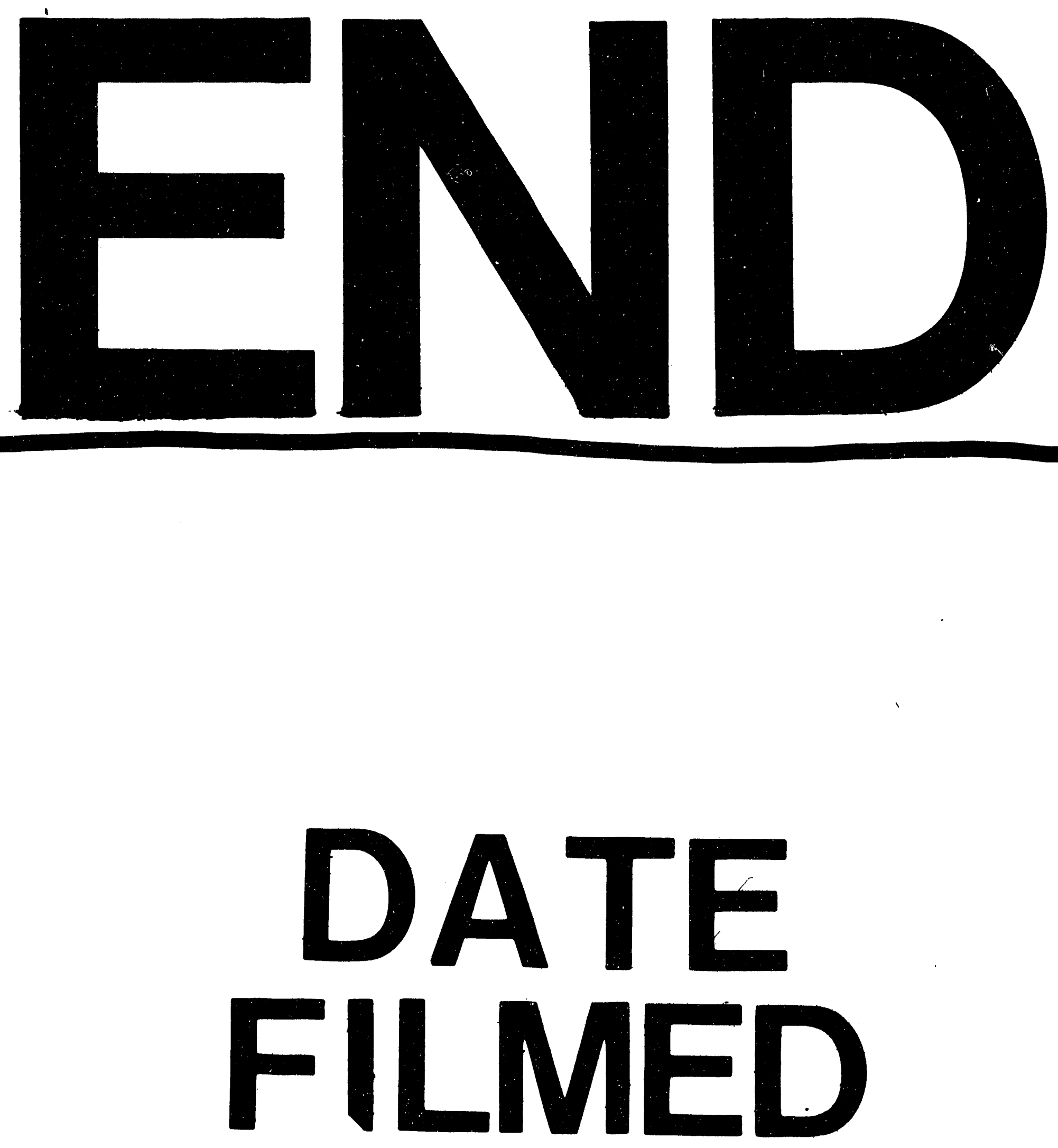

$9 / 8 / 93$ 